\title{
Red sandstone as raw material of Baden culture (Late Copper Age) grinding stones (Balatonőszöd - Temetői dülő site, Hungary), with a review of the red sandstone formations of SW Hungary
}

\author{
Bálint Péterdi \\ Mining and Geological Survey of Hungary. Department of Geological and Geophysical Collections, Stefánia út \\ 14., H-1143, Budapest, Hungary. Email: peterdi.balint@gmail.com
}

\begin{abstract}
:
Balatonőszöd - Temetöi dülö is one of the largest excavated and longest-lived sites of the Late Copper Age Baden Culture in Hungary, where 500 lithic finds were registered. In the site finds belonging to the late Middle Copper Age Balaton-Lasinja Culture and the Late Copper Age Boleraz Culture were found too.

This paper presents petrographic and geochemical analyses of stone utensils, mostly of grinding stones, made of red, or discoloured white sandstones.

Almost all sandstone artefacts are upper and lower stones of grinding equipment and polishers, as well as objects whose function is not known, worked and non-worked fragments; boulders of raw material are also in the studied set.

The detailed petrographic and geochemical methods applied here are polarized light microscopy and a distribution study of the framework grains in thin section, and ICP-OES and ICP-MS as bulk rock chemical methods. The results were compared to published petrographic and geochemical data.

Most of the studied artefacts were made of the rocks of the Red Sandstone and Siltstone Member of the Balaton Highland Sandstone Formation, especially from the mature type sandstone in which quartz is predominant, and which is almost free of feldspar. This type is characteristic of the confines of the Southern Balaton Highland and the lower part of the formation in the Northern Balaton Highland.

A minor part of the studied artefacts - red or purple, purplish grey sandstones - originates from the sandstones of the Jakabhegy Sandstone Formation (Western Mecsek mountains).
\end{abstract}

Keywords: sandstone; grinding stone; petrography; Baden Culture; Balatonőszöd (Hungary); provenance

\section{Archaeological background, aim of the study}

Balatonőszöd - Temetői dülő is one of the largest excavated and longest-lived archaeological sites of the Late Copper Age Baden Culture in Hungary. The total area of the excavated and the connected registered site is more than $200,000 \mathrm{~m}^{2}$. (Figure 1). The site's

Published by the School of History, Classics and Archaeology, University of Edinburgh ISSN: 2055-0472. URL: http://journals.ed.ac.uk/lithicstudies/

Except where otherwise noted, this work is licensed under a CC BY 4.0 licence. 
flourishing time lasted for almost 500 years (3330-2860 cal. BCE, the latest measured date was 2740-2590 cal. BCE). On the site, features of the late Middle Copper Age BalatonLasinja Culture (3950-3690 cal. BCE) and the Late Copper Age Boleraz Culture (formerly known as the Boleraz phase of the Baden Culture, 3470-2900 cal. BCE) were also found. Some features of the three cultures occurred together (mixed) though no traces of any later digging in or upsetting could be observed in the section (Horváth 2010; 2014; Horváth et al. 2006).

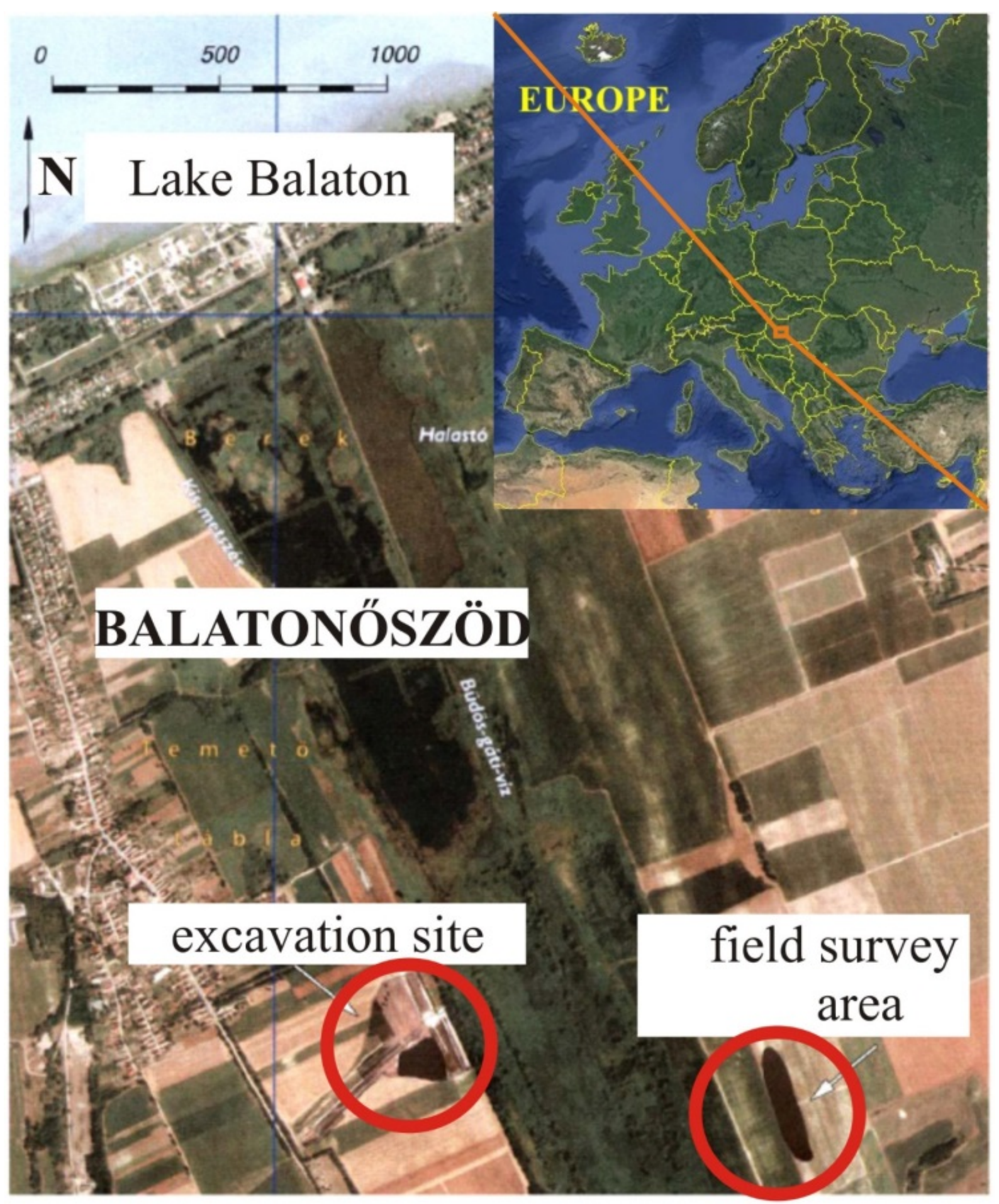

Figure 1. The archaeological site (Balatonőszöd - Temetői dülö) and its surroundings (Horváth et al. 2006, modified, original aerial photo and picture by Zsolt Viemann) 
Altogether 500 lithic finds were registered. Their archaeological classification was carried out by Tünde Horváth. 65 percent of the lithic finds were ground stone artefacts (327 pieces), most of them fragments of grinding upper and lower stones. On a few of them, traces of mineral pigments were observed. Polishers and others (objects whose function is not known, worked and non-worked fragments, and boulders of raw material) were also found. Of the lithic finds, 35\% were polished stone tools, mainly stone axe preforms, a few axes and cores of shaft-hole axes.

From a geological point of view, more than 57 percent of the ground stone artefacts (188 pieces) was made of "red" or bleached, discoloured red sandstone.

The general aim of this study is the detailed petrographic and geochemical examination of the "red” sandstone artefacts found on the Balatonöszöd - Temetöi dülö archaeological site and to reach a conclusion for the origin of the raw-materials. For comparison, data was used from recently gathered red sandstone samples and data from geological literature. Additionally, the study gives an introduction to the red sandstones of SW-Hungary as possible raw material of artefacts.

\section{Methods}

The material of the lithic finds found at Balatonőszöd - Temetői dülő was classified on the basis of macroscopic analyses. To carry out detailed petrographic microscopic analyses, thin sections were made from samples of a given group, either from fragments or from pieces having less value from an archaeological point of view. Beside petrographic microscopic analyses, bulk-rock geochemical examinations were carried out by ICP-OES and ICP-MS.

The proportions of the clastic constituents (distribution of the framework grains) of the finds examined in thin section were measured by band-counting and represented in the quartzfeldspar-rock fragments ternary diagram, according to Chayes (1956), Dickinson (1970), Pettijohn et al. (1973), and Dickinson \& Suczek (1979). The results were compared to data from studies by Csernussi (1984), Fazekas (1987; 1989), Fülöp (1990), and Majoros (1998).

Bulk-rock chemical analyses by ICP-OES and ICP-MS of the selected finds and recently gathered red sandstone samples from the Balaton Highland were performed at the ACME Analytical Laboratories (Vancouver, Canada) and the results were compared to data of analyses by Csernussi (1984), Varga et al. (2007), and Varga (2009). The samples were prepared as follows: a $5 \mathrm{~g}$ piece was cut from a chosen archaeological or geological sample. This piece was powdered and the powder was homogenized. For major element investigation $0.200 \mathrm{~g}$ was taken from the homogenized powder, was fused with $\mathrm{LiBO}_{2}$, and then analysed by ICP-OES. Total carbon and total sulphur were measured by a LECO carbon-sulphur analyzer, and these data were not included in the sum. For trace element investigation $0.50 \mathrm{~g}$ was taken from the homogenized powder and was leached with $3 \mathrm{ml} 2-2-2-\mathrm{HCl}-\mathrm{HNO}_{3}-\mathrm{H}_{2} \mathrm{O}$ at $95^{\circ} \mathrm{C}$ for one hour, then diluted to $10 \mathrm{ml}$ and analysed by ICP-MS. For REE investigation $0.200 \mathrm{~g}$ was taken from the homogenized powder and was fused with $\mathrm{LiBO}_{2}$ then analysed by ICP-MS.

\section{Results}

\subsection{Results - Macroscopic petrography}

On the basis of macroscopic features certain raw material groups could be distinguished.

\subsubsection{Group I (183 pieces)}

Group I consists of moderately or well sorted sandstones with varying grain-size. Main components are quartz and micas (primarily discoloured, chloritized biotite). The quantity of 
the matrix and the cementation is very small in comparison to the mineral grains. On the basis of their colour this group has been divided into two subgroups:

Subgroup I/1 (131 specimens): in general, they are typical red sandstones, but there are also orange-red, purplish-red (and darker, with a greyish shade) species in this subgroup. (Figure 2a).

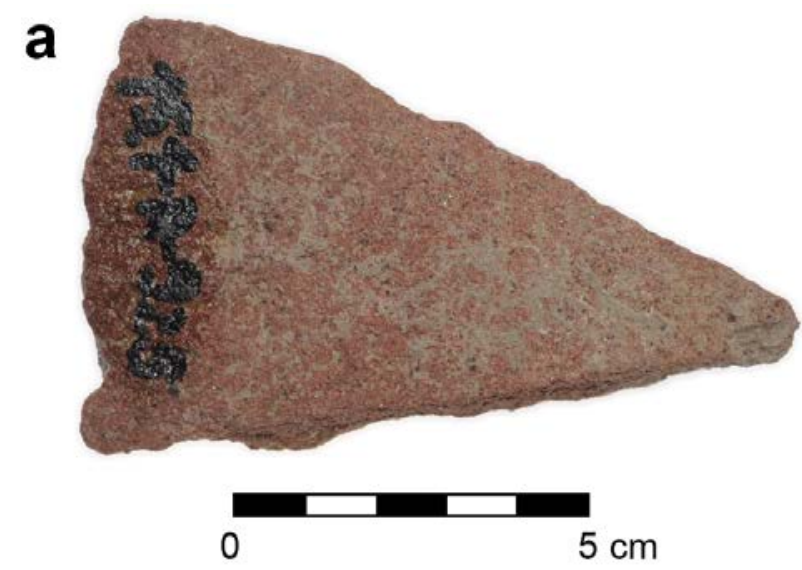

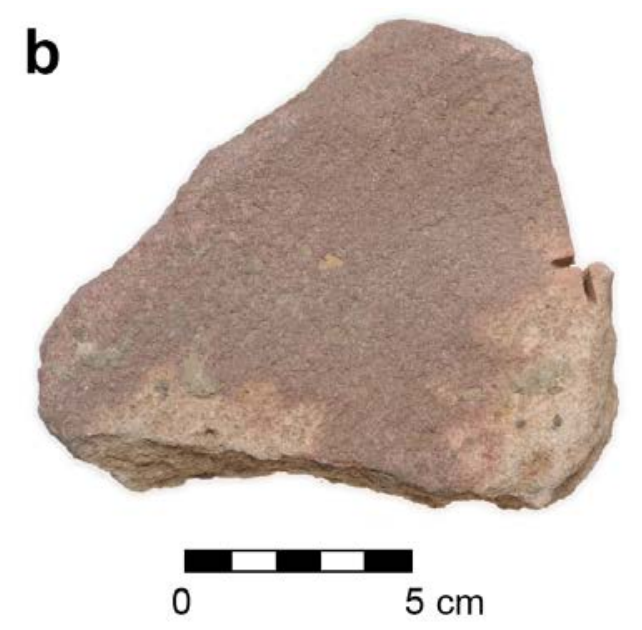

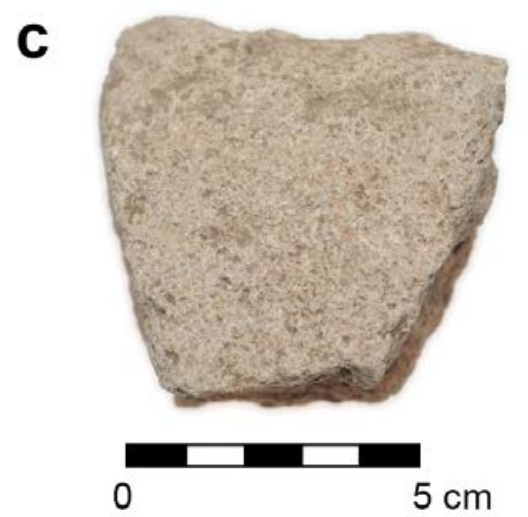

Figure 2. (Group I) Macroscopic photos: a) red sandstone (Subgroup I/1). b) partly discoloured red sandstone (transition between Subgroup I/1 and I/2). c) discoloured “red” sandstone (Subgroup I/2).

Subgroup I/2 (52 specimens): in general, these sandstones are discoloured, they are light coloured (a pale shade of grey to almost white), with - sporadically - faintly reddish, orangered, occasionally yellow or purplish-grey coloured patches of weathering. (Figure 2c).

The originally red colour of the discoloured specimens clearly shows in ten of the examined finds that have both red and "white" (i.e., a pale shade of grey, discoloured) parts. These pieces have been assigned to Subgroup I/1. (Figure 2b). The discolouration (bleaching) of red sandstones is a well-known feature in geological deposits of the Balatonfelvidék Sandstone Formation (see section 4.1.), but in the case of an artefact we cannot exclude postdepositional alterations.

\subsubsection{Group II (5 pieces)}

Group II comprises purplish grey, purple, red mottled, coarse- or medium-grained, clastsupported sandstones. Quartz is their main component. Among the coarse sand grains, there are poorly rounded quartz- and quartzite-pebbles, with a maximum size of $1.5 \mathrm{~cm}$. White or occasionally pale red, angular feldspar-grains, not bigger than $1 \mathrm{~mm}$, are also observable. The appearance of the detrital micas occurring in this group is similar to the ones in Group I, but in smaller quantities and smaller sizes than those in Group I (Figure 3). 


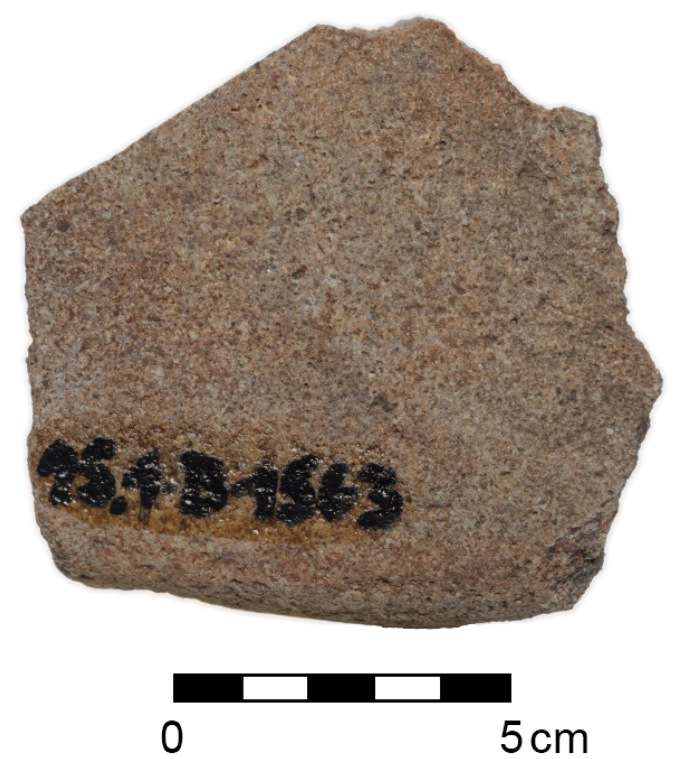

Figure 3. (Group II) Macroscopic photos: red sandstones.

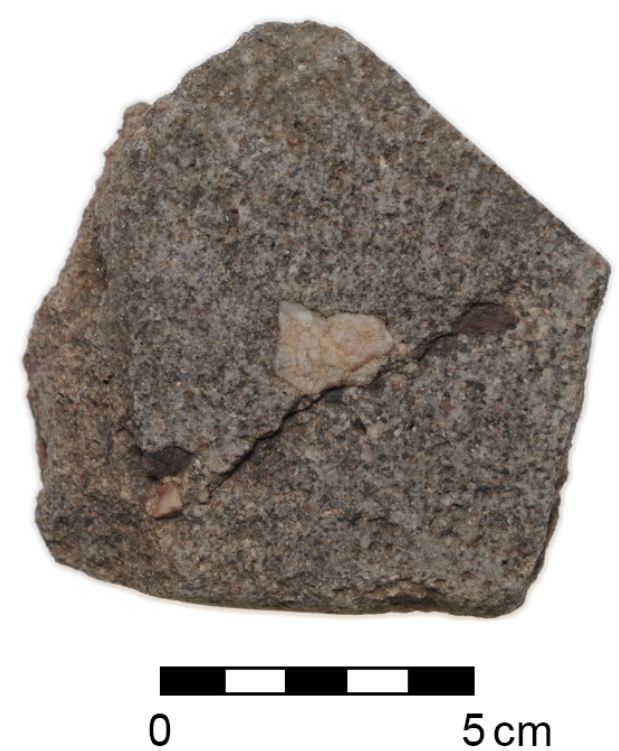

\subsection{Results - Microscopic petrography and distribution of the framework grains}

\subsubsection{Group I}

In thin section, the two subgroups do not differ from each other at all. The grains - as a whole - are unrounded or only slightly subangular.

Constituents:

- detrital, unrounded or only slightly rounded quartz grains (Figure 4);

- polycrystalline quartz grains (Figure 5a);

- detrital micas (chloritized biotite and muscovite; Figure 5b);

- rock fragments (volcanic): acidic volcanic rock fragments (Figure 6a);

- rock fragments (metamorphic): deformational fabric (banded) polycrystalline quartzite-rock lithoclasts and a few phyllite grains (Figure 5a);

- usually decomposed magnetite grains (Figure 6b);

- limonite (hematite) as crust on the fringe of grains and in the cement (Figure 7a).

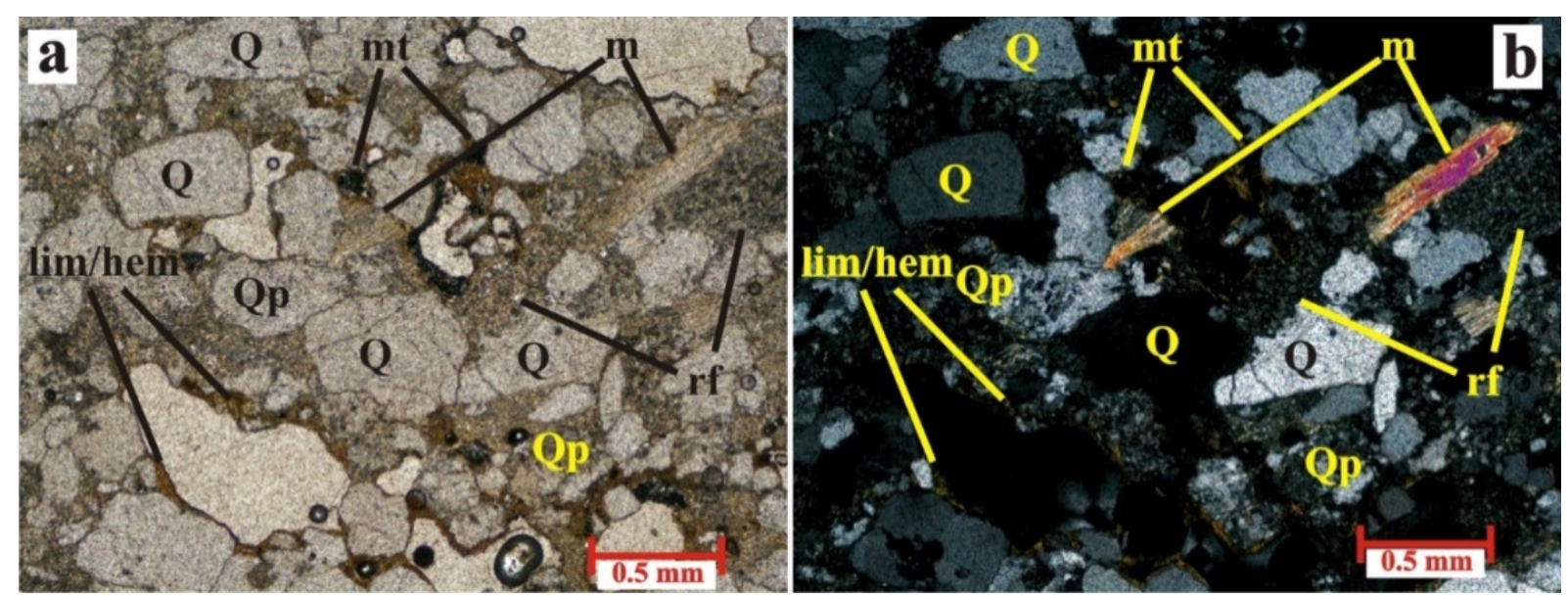

Figure 4. (Group I) Photomicrograph a) plane-polarized light, b) cross-polarized light): rock texture with monocrystalline quartz $(\mathrm{Q})$, polycrystalline quartz (Qp), mica (discoloured or chloritized biotite) (m), altered acidic volcanic rock fragment (rf), magnetite (mt), limonite-hematite (lim-hem). 


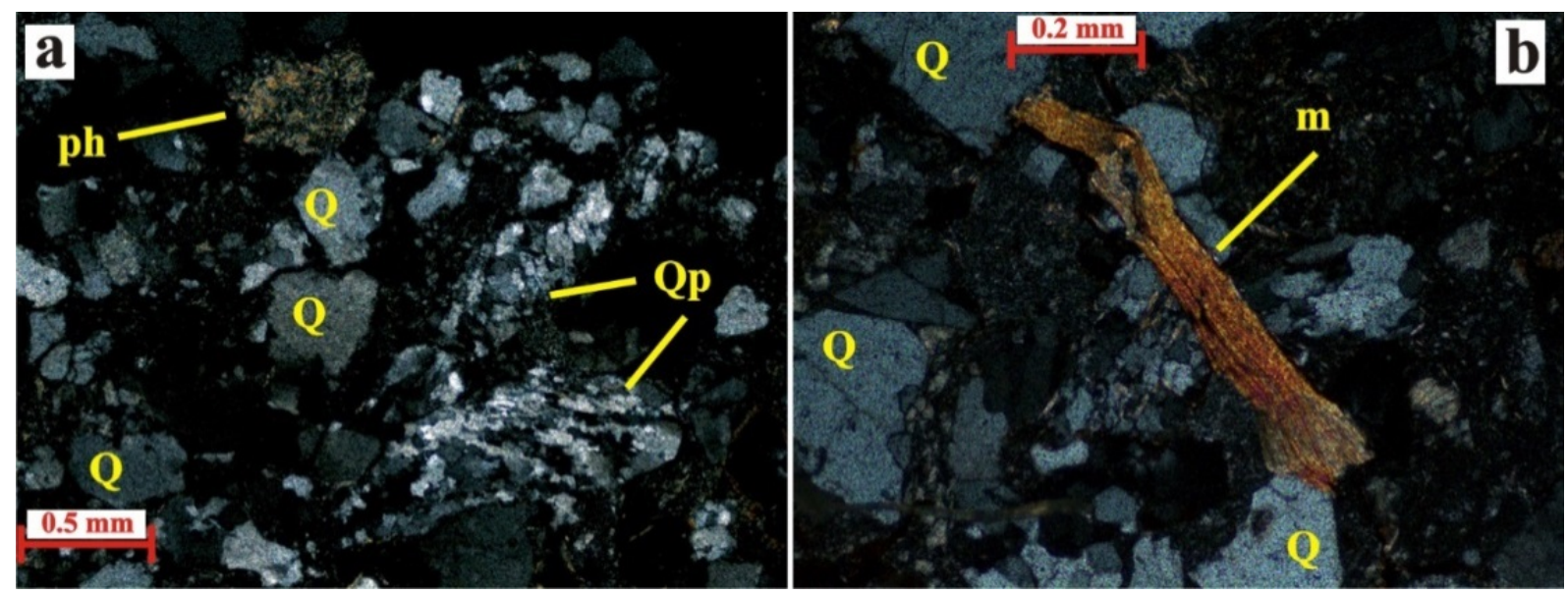

Figure 5. (Group I) a) Photomicrograph (cross-polarized light): rock texture with monocrystalline quartz (Q), polycrystalline quartz (Qp), phyllite fragment (ph). b) Photomicrograph (cross-polarized light): mica (biotite) (m).
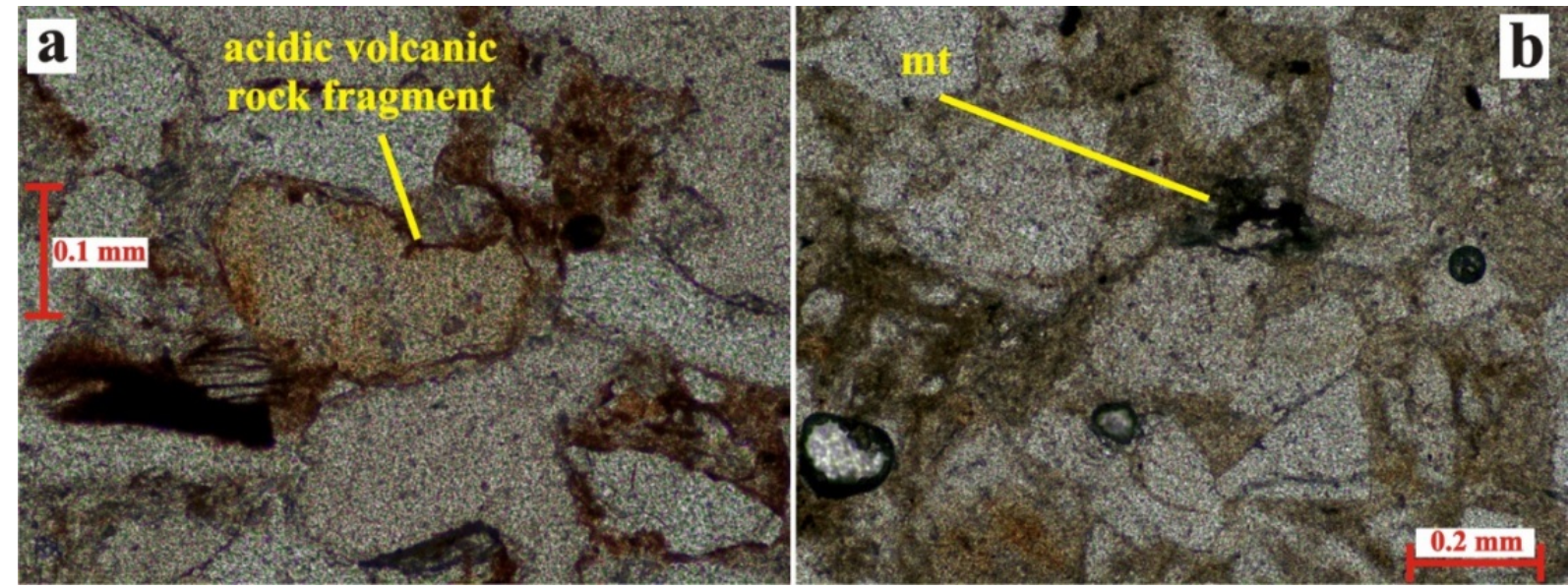

Figure 6. (Group I) a) Photomicrograph (plane-polarized light): rock fragment (acidic volcanic rock). b) Photomicrograph (plane-polarized light): decomposed magnetite (mt).

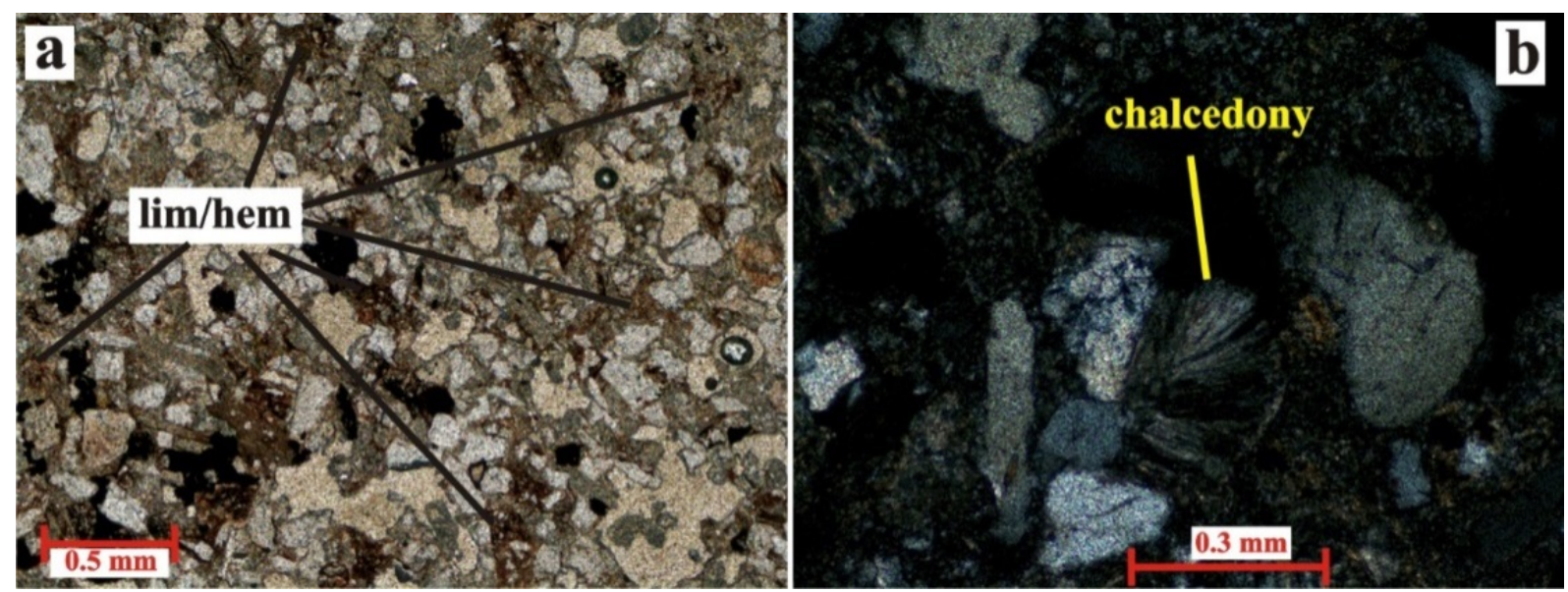

Figure 7. (Group I) a) Photomicrograph (plane-polarized light): limonite-hematite coatings on the surfaces of some of the crystals and in the cementation (lim - hem). b) Photomicrograph (cross-polarized light): cavityfilling chalcedony.

Quartz prevail among the grains, but polycrystalline quartz is also present in great quantity. The quantity of the volcanic rock fragments is higher than the quantity of metamorphic clasts. An important feature is the total absence of feldspars. The cement is 
limonitic-hematitic (which causes the red, occasionally orange or purplish colour of the rock when examined macroscopically), siliceous or carbonatized (possibly secondarily). Chalcedony - though very rarely - is also observable (Figure $7 \mathrm{~b}$ ). The porosity of the samples is insignificant, their fabric is compact. The few pores and interstices are mainly filled with chalcedony during lithification, though chlorite filling also occurs.

\subsubsection{Group II}

Constituents:

- clastic, unrounded (or only slightly rounded) quartz grains (Figure 8);

- generally rounded polycrystalline quartz grains (Figure 8);

- detrital micas (muscovite and discoloured, chloritized biotite; Figure 9);

- rock fragments (volcanic): grains with felsitic texture (Figure 10a) and spherulitic volcanic glass clasts (Figure 10b);

- rock fragments (metamorphic): deformational fabric (banded) polycrystalline quartzite-rock lithoclasts;

- feldspars (plagioclase and microcline; Figure 11a);

- siltstone lithoclasts (Figure 11b);

- magnetite.

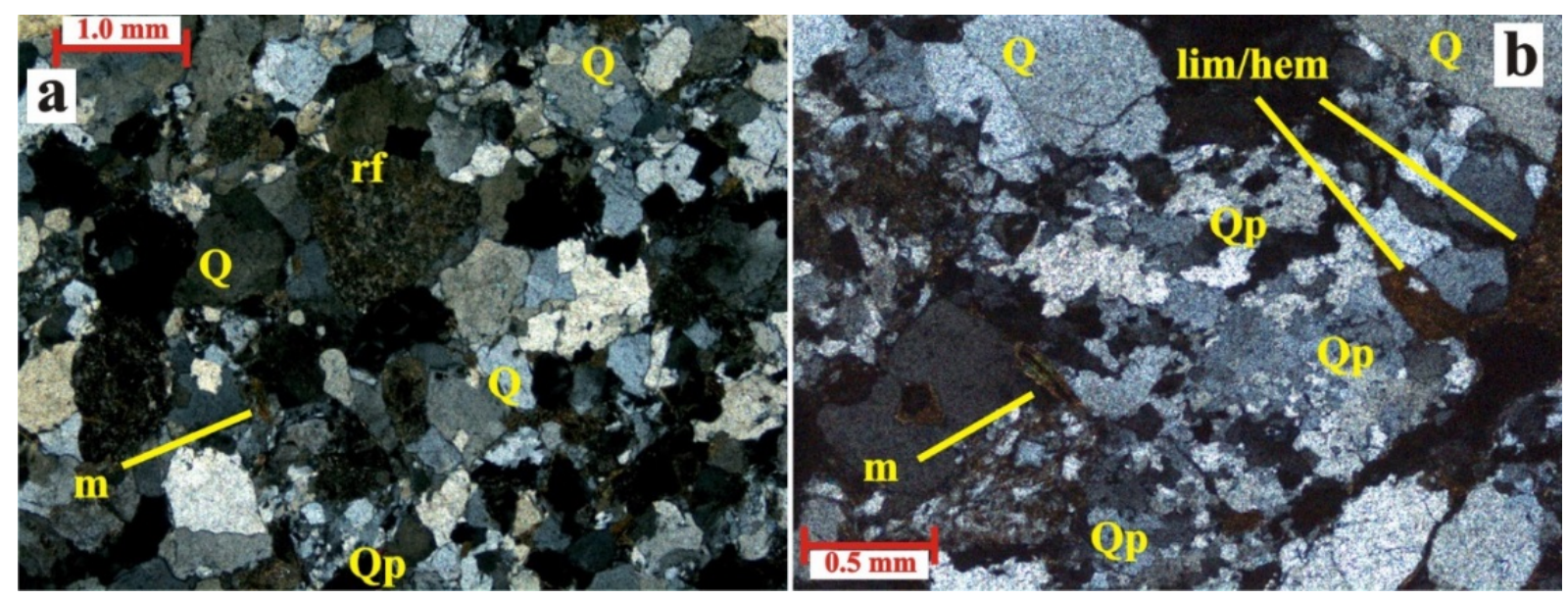

Figure 8. (Group II) a) Photomicrograph (cross-polarized light): rock texture with monocrystalline quartz (Q), polycrystalline quartz (Qp), mica (m), altered acidic vulcanite fragment (rf). b) Photomicrograph (crosspolarized light): rock texture with monocrystalline quartz $(\mathrm{Q})$, polycrystalline quartz (Qp), mica (m), limonitehematite (lim - hem).
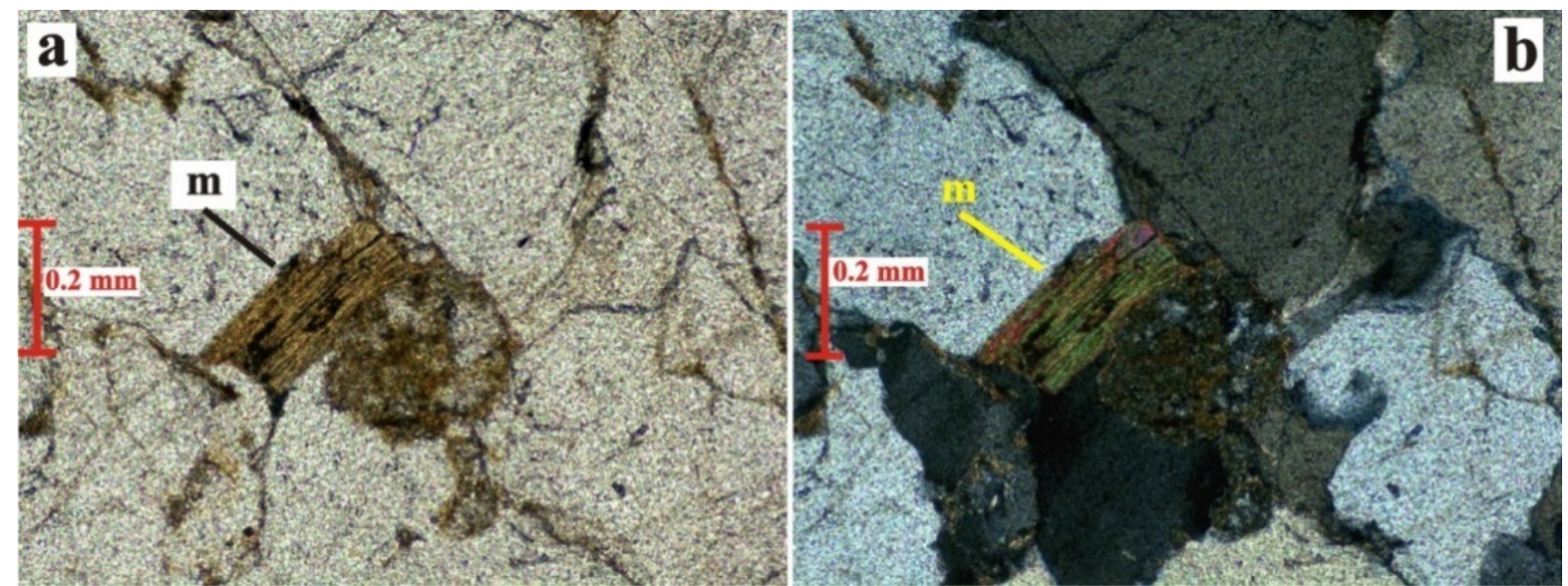

Figure 9. (Group II) Photomicrograph (a) plane-polarized light, b) cross-polarized light: mica (biotite) (m). 

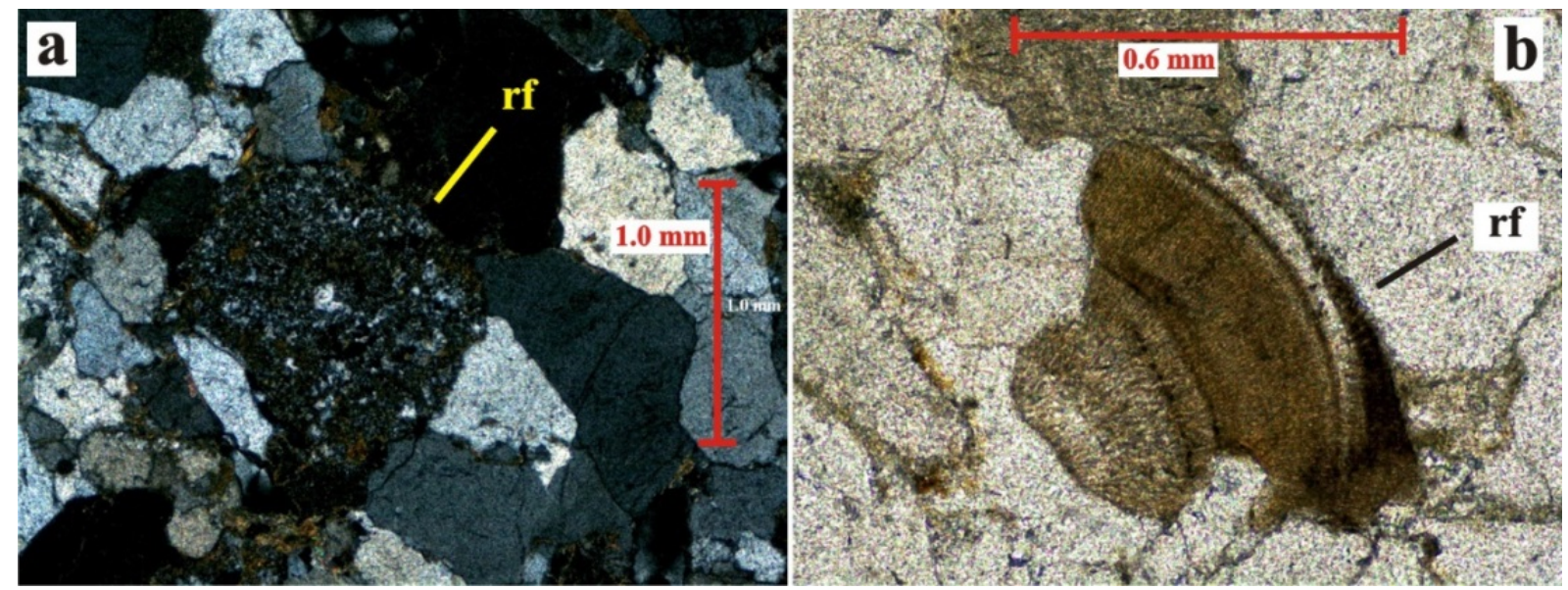

Figure 10. (Group II) a) Photomicrograph (cross-polarized light): rock fragment (rf): grain with felsitic texture (from acidic volcanic rock). b) Photomicrograph (plane-polarized light): rock fragment (rf): spherulitic volcanic glass (from acidic volcanic rock).
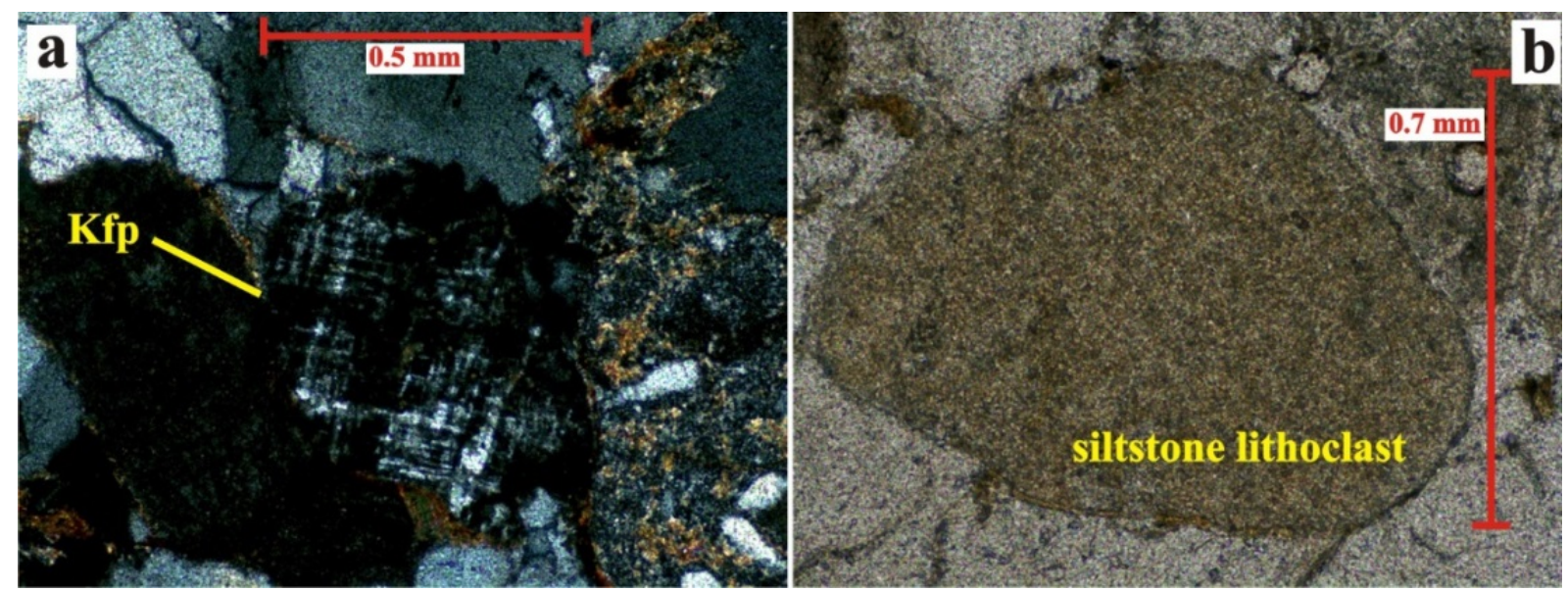

Figure 11. (Group II) a) Photomicrograph (cross-polarized light): K-feldspar (microcline) (Kfp). b) Photomicrograph (plane-polarized light): siltstone lithoclast.

Major constituents are monocrystalline and polycrystalline quartz grains. The appearance of the detrital micas is similar to the ones in Group I, but in smaller quantities and smaller grain size. The size and quantity of the magnetite grains are also smaller than in Group I. Characteristic features - compared to Group I - are the presence of feldspars and of siltstone lithoclasts. Practically, there is no matrix, the fabric of the rock is even more packed than in Group I, however, limonitic fillings of cavities occur (Figure 8b).

\subsubsection{Distribution of the framework grains}

On the basis of the proportion of the clastic constituents, the studied members of Subgroup I/1 and I/2 are lithic arenites (litharenites) and sublitharenites and the studied members of Group II are classified as a transitional composition between subarkoses and sublitharenites.

\subsection{Results - Bulk rock chemistry}

The bulk rock chemical data (ICP-OES and ICP-MS results) of the studied artefacts and recently gathered red sandstone comparative samples (from the Balaton Highland) are presented in Tables 1-4. 
Table 1. Bulk-rock chemistry. ICP-OES and ICP-MS results of the studied artefacts. (Major elements in weightpercent, trace elements and REE in ppm.)

\section{Artefacts}

\begin{tabular}{|c|c|c|c|c|c|}
\hline & & & & & \\
\hline percent & $\mathrm{SiO}_{2}$ & 74.94 & 86.93 & 85.10 & 88.70 \\
\hline & $\mathrm{Al}_{2} \mathrm{O}_{3}$ & 10.31 & 8.26 & 9.50 & 5.62 \\
\hline & $\mathrm{Fe}_{2} \mathrm{O}_{3}$ & 5.52 & 0.71 & 0.54 & 0.96 \\
\hline & $\mathrm{MgO}$ & 0.16 & 0.06 & 0.10 & 0.13 \\
\hline & $\mathrm{CaO}$ & 1.97 & 0.08 & 0.29 & 0.16 \\
\hline & $\mathrm{Na}_{2} \mathrm{O}$ & 0.06 & 0.02 & 0.05 & 0.13 \\
\hline & $\mathrm{K}_{2} \mathrm{O}$ & 0.68 & 0.43 & 0.47 & 3.35 \\
\hline & $\mathrm{TiO}_{2}$ & 0.46 & 0.28 & 0.20 & 0.07 \\
\hline & $\mathrm{P}_{2} \mathrm{O}_{5}$ & 0.18 & 0.04 & 0.12 & 0.13 \\
\hline & $\mathrm{MnO}$ & 0.22 & 0.01 & 0.05 & 0.01 \\
\hline & $\mathrm{Cr}_{2} \mathrm{O}_{3}$ & $<0.01$ & $<0.01$ & $<0.01$ & $<0.01$ \\
\hline & LOI & 5.30 & 3.20 & 3.60 & 0.60 \\
\hline & SUM & 99.80 & 100.02 & 100.02 & 99.86 \\
\hline ppm & $\mathrm{Rb}$ & 29.90 & 18.50 & 23.10 & 72.60 \\
\hline & $\mathrm{Ba}$ & 166.90 & 98.40 & 72.90 & 477.40 \\
\hline & Th & 11.60 & 5.70 & 6.00 & 4.10 \\
\hline & $\mathrm{Nb}$ & 6.90 & 5.10 & 4.50 & 2.30 \\
\hline & $\mathrm{Pb}$ & 2.9 & 5.3 & 2.6 & 1.9 \\
\hline & $\mathrm{Sr}$ & 111.80 & 45.00 & 124.40 & 208.30 \\
\hline & $\mathrm{Zr}$ & 287.80 & 141.40 & 86.80 & 58.40 \\
\hline & $Y$ & 24.30 & 13.00 & 10.70 & 6.90 \\
\hline $\mathrm{ppm}$ & $\mathrm{La}$ & 28.5 & 11 & 22.3 & 9.8 \\
\hline & $\mathrm{Ce}$ & 61.4 & 20.7 & 43.7 & 19.1 \\
\hline & $\mathrm{Pr}$ & 7.22 & 2.43 & 4.93 & 2.11 \\
\hline & $\mathrm{Nd}$ & 30.6 & 9.1 & 17.6 & 8 \\
\hline & $\mathrm{Sm}$ & 6.4 & 1.8 & 2.8 & 1.5 \\
\hline & $\mathrm{Eu}$ & 1.11 & 0.33 & 0.6 & 0.44 \\
\hline & $\mathrm{Gd}$ & 5.12 & 1.52 & 1.88 & 1.4 \\
\hline & $\mathrm{Tb}$ & 0.7 & 0.29 & 0.22 & 0.16 \\
\hline & Dy & 4.27 & 1.82 & 1.48 & 1.11 \\
\hline & $\mathrm{Ho}$ & 0.83 & 0.42 & 0.34 & 0.23 \\
\hline & $\mathrm{Er}$ & 2.39 & 1.22 & 0.98 & 0.65 \\
\hline & $\mathrm{Tm}$ & 0.42 & 0.22 & 0.18 & 0.1 \\
\hline & $\mathrm{Yb}$ & 2.47 & 1.24 & 1.09 & 0.57 \\
\hline & Lu & 0.37 & 0.2 & 0.16 & 0.09 \\
\hline
\end{tabular}


Table 2. Bulk-rock chemistry. ICP-OES and ICP-MS results of comparative samples from the Balaton-Highland. (Major elements in weight-percent, trace elements and REE in ppm.)

\section{Comparative sandstone samples}

(Pálköve)

\begin{tabular}{|c|c|c|c|c|c|c|c|}
\hline & & sample 1 & sample 2 & sample 3 & sample 4 & sample 5 & sample 6 \\
\hline \multirow{13}{*}{ percent } & $\mathrm{SiO}_{2}$ & 83.24 & 84.03 & 79.40 & 75.85 & 67.42 & 69.17 \\
\hline & $\mathrm{Al}_{2} \mathrm{O}_{3}$ & 9.80 & 8.70 & 11.78 & 13.99 & 16.83 & 16.70 \\
\hline & $\mathrm{Fe}_{2} \mathrm{O}_{3}$ & 2.32 & 3.28 & 3.11 & 3.36 & 6.85 & 5.50 \\
\hline & $\mathrm{MgO}$ & 0.05 & 0.03 & 0.07 & 0.13 & 0.25 & 0.21 \\
\hline & $\mathrm{CaO}$ & 0.10 & 0.06 & 0.04 & 0.05 & 0.07 & 0.08 \\
\hline & $\mathrm{Na}_{2} \mathrm{O}$ & 0.02 & 0.02 & 0.03 & 0.06 & 0.07 & 0.07 \\
\hline & $\mathrm{K}_{2} \mathrm{O}$ & 0.47 & 0.41 & 0.66 & 1.11 & 1.62 & 1.45 \\
\hline & $\mathrm{TiO}_{2}$ & 0.31 & 0.26 & 0.43 & 0.52 & 0.86 & 0.86 \\
\hline & $\mathrm{P}_{2} \mathrm{O}_{5}$ & 0.14 & 0.08 & 0.05 & 0.06 & 0.08 & 0.06 \\
\hline & $\mathrm{MnO}$ & 0.01 & 0.01 & 0.01 & 0.01 & 0.01 & 0.01 \\
\hline & $\mathrm{Cr}_{2} \mathrm{O}_{3}$ & $<0.01$ & $<0.01$ & 0.01 & 0.01 & 0.01 & 0.01 \\
\hline & LOI & 3.40 & 3.10 & 4.40 & 4.70 & 5.70 & 5.70 \\
\hline & SUM & 99.86 & 99.98 & 99.99 & 99.85 & 99.77 & 99.82 \\
\hline \multirow[t]{8}{*}{ ppm } & $\mathrm{Rb}$ & 23.80 & 21.40 & 35.50 & 48.90 & 84.30 & 74.50 \\
\hline & $\mathrm{Ba}$ & 96.50 & 47.70 & 70.80 & 114.40 & 186.50 & 161.50 \\
\hline & Th & 11.10 & 19.20 & 9.80 & 8.00 & 10.90 & 8.70 \\
\hline & $\mathrm{Nb}$ & 5.30 & 7.10 & 7.10 & 9.20 & 14.00 & 14.50 \\
\hline & $\mathrm{Pb}$ & 3.6 & 3.1 & 2.7 & 3.1 & 4.6 & 3.7 \\
\hline & $\mathrm{Sr}$ & 196.70 & 176.10 & 102.10 & 97.50 & 386.20 & 124.50 \\
\hline & $\mathrm{Zr}$ & 117.70 & 124.80 & 287.50 & 152.30 & 185.40 & 181.70 \\
\hline & $Y$ & 17.70 & 110.10 & 32.30 & 20.40 & 30.80 & 19.70 \\
\hline \multirow[t]{14}{*}{ ppm } & $\mathrm{La}$ & 32.6 & 42.3 & 20.2 & 20.2 & 38 & 27.1 \\
\hline & $\mathrm{Ce}$ & 61.7 & 86.4 & 43.5 & 41.6 & 83.4 & 57.8 \\
\hline & $\mathrm{Pr}$ & 7.47 & 9.14 & 4.7 & 4.82 & 9.52 & 5.87 \\
\hline & $\mathrm{Nd}$ & 27.9 & 32.5 & 18.9 & 18.6 & 40.6 & 20.3 \\
\hline & $\mathrm{Sm}$ & 4.7 & 6 & 4.2 & 3.3 & 9.4 & 3 \\
\hline & $\mathrm{Eu}$ & 0.67 & 1.56 & 0.97 & 0.66 & 1.74 & 0.53 \\
\hline & $\mathrm{Gd}$ & 2.48 & 10.64 & 4.35 & 3.07 & 7.4 & 2.57 \\
\hline & $\mathrm{Tb}$ & 0.31 & 2.39 & 0.7 & 0.44 & 0.83 & 0.36 \\
\hline & Dy & 2.52 & 17.76 & 5.26 & 3.12 & 4.69 & 3.17 \\
\hline & $\mathrm{Ho}$ & 0.58 & 3.53 & 1.02 & 0.71 & 0.99 & 0.65 \\
\hline & $\mathrm{Er}$ & 1.66 & 10.13 & 3.08 & 2.09 & 2.63 & 1.95 \\
\hline & $\mathrm{Tm}$ & 0.27 & 1.4 & 0.5 & 0.39 & 0.41 & 0.36 \\
\hline & $\mathrm{Yb}$ & 1.73 & 8.27 & 3.07 & 2.39 & 2.49 & 2.18 \\
\hline & Lu & 0.25 & 1.09 & 0.43 & 0.37 & 0.43 & 0.32 \\
\hline
\end{tabular}


Table 3. Bulk-rock chemistry. ICP-OES and ICP-MS results of comparative samples from the Balaton-Highland (continuation). (Major elements in weight-percent, trace elements and REE in ppm.)

Comparative sandstone samples

Balatonrendes

\begin{tabular}{|c|c|c|c|c|}
\hline & & sample 7 & sample 8 & sample 9 \\
\hline \multirow[t]{13}{*}{ percent } & $\mathrm{SiO}_{2}$ & 68.42 & 69.45 & 82.74 \\
\hline & $\mathrm{Al}_{2} \mathrm{O}_{3}$ & 17.02 & 17.71 & 10.29 \\
\hline & $\mathrm{Fe}_{2} \mathrm{O}_{3}$ & 5.75 & 4.27 & 2.11 \\
\hline & MgO & 0.21 & 0.17 & 0.21 \\
\hline & $\mathrm{CaO}$ & 0.08 & 0.06 & 0.13 \\
\hline & $\mathrm{Na}_{2} \mathrm{O}$ & 0.07 & 0.05 & 0.03 \\
\hline & $\mathrm{K}_{2} \mathrm{O}$ & 1.49 & 1.23 & 0.44 \\
\hline & $\mathrm{TiO}_{2}$ & 0.86 & 0.79 & 0.22 \\
\hline & $\mathrm{P}_{2} \mathrm{O}_{5}$ & 0.08 & 0.06 & 0.03 \\
\hline & $\mathrm{MnO}$ & 0.01 & 0.01 & 0.01 \\
\hline & $\mathrm{Cr}_{2} \mathrm{O}_{3}$ & 0.01 & 0.01 & 0.01 \\
\hline & LOI & 5.80 & 6.10 & 3.80 \\
\hline & SUM & 99.80 & 99.91 & 100.02 \\
\hline \multirow[t]{8}{*}{ ppm } & $\mathrm{Rb}$ & 74.80 & 63.00 & 22.00 \\
\hline & $\mathrm{Ba}$ & 170.90 & 126.60 & 52.10 \\
\hline & Th & 12.60 & 11.00 & 7.00 \\
\hline & $\mathrm{Nb}$ & 14.20 & 13.50 & 5.20 \\
\hline & $\mathrm{Pb}$ & 4.5 & 3.3 & 1.5 \\
\hline & $\mathrm{Sr}$ & 217.50 & 200.60 & 58.90 \\
\hline & $\mathrm{Zr}$ & 172.80 & 392.40 & 105.40 \\
\hline & $Y$ & 20.00 & 25.40 & 24.20 \\
\hline \multirow[t]{14}{*}{ ppm } & La & 36.8 & 45.7 & 15 \\
\hline & $\mathrm{Ce}$ & 72.2 & 86.7 & 29.4 \\
\hline & $\operatorname{Pr}$ & 7.57 & 9.98 & 3.67 \\
\hline & $\mathrm{Nd}$ & 23.8 & 34.4 & 13.4 \\
\hline & $\mathrm{Sm}$ & 3.4 & 5.5 & 2.7 \\
\hline & $\mathrm{Eu}$ & 0.8 & 1.15 & 0.56 \\
\hline & $\mathrm{Gd}$ & 2.7 & 4.15 & 3.31 \\
\hline & $\mathrm{Tb}$ & 0.4 & 0.5 & 0.57 \\
\hline & Dy & 3.08 & 3.74 & 4.12 \\
\hline & Ho & 0.68 & 0.83 & 0.8 \\
\hline & $\mathrm{Er}$ & 2.04 & 2.58 & 2.27 \\
\hline & $\mathrm{Tm}$ & 0.36 & 0.45 & 0.34 \\
\hline & $\mathrm{Yb}$ & 2.16 & 2.93 & 2.09 \\
\hline & $\mathrm{Lu}$ & 0.38 & 0.48 & 0.31 \\
\hline
\end{tabular}


Table 4. Bulk-rock chemistry. ICP-OES and ICP-MS results of comparative samples from the Balaton-Highland (continuation). (Major elements in weight-percent, trace elements and REE in ppm.)

\begin{tabular}{|c|c|c|c|c|c|}
\hline & \multicolumn{4}{|c|}{ Comparative sandstone samples } \\
\hline & & \multirow{2}{*}{$\begin{array}{c}\text { Alsóörs } \\
\text { sample } 10\end{array}$} & \multirow{2}{*}{$\begin{array}{c}\text { Köcsi-tó } \\
\text { sample } 11 \\
\end{array}$} & \multicolumn{2}{|c|}{ Balatonalmádi } \\
\hline & & & & sample 12 & sample 13 \\
\hline \multirow{13}{*}{ percent } & $\mathrm{SiO}_{2}$ & 66.85 & 85.82 & 82.77 & 82.61 \\
\hline & $\mathrm{Al}_{2} \mathrm{O}_{3}$ & 17.39 & 8.62 & 10.16 & 10.34 \\
\hline & $\mathrm{Fe}_{2} \mathrm{O}_{3}$ & 6.49 & 1.81 & 1.94 & 1.93 \\
\hline & $\mathrm{MgO}$ & 0.43 & 0.03 & 0.08 & 0.08 \\
\hline & $\mathrm{CaO}$ & 0.09 & 0.02 & 0.03 & 0.02 \\
\hline & $\mathrm{Na}_{2} \mathrm{O}$ & 0.09 & 0.02 & 0.03 & 0.03 \\
\hline & $\mathrm{K}_{2} \mathrm{O}$ & 2.53 & 0.45 & 0.46 & 0.46 \\
\hline & $\mathrm{TiO}_{2}$ & 0.85 & 0.21 & 0.28 & 0.28 \\
\hline & $\mathrm{P}_{2} \mathrm{O}_{5}$ & 0.07 & 0.03 & 0.04 & 0.04 \\
\hline & $\mathrm{MnO}$ & 0.11 & 0.01 & 0.01 & 0.01 \\
\hline & $\mathrm{Cr}_{2} \mathrm{O}_{3}$ & 0.01 & $<0.01$ & $<0.01$ & $<0.01$ \\
\hline & LOI & 4.90 & 3.00 & 4.20 & 4.20 \\
\hline & SUM & 99.81 & 100.02 & 100.00 & 100.00 \\
\hline \multirow[t]{8}{*}{ ppm } & $\mathrm{Rb}$ & 98.20 & 17.90 & 20.20 & 20.20 \\
\hline & $\mathrm{Ba}$ & 642.80 & 74.50 & 131.40 & 143.00 \\
\hline & Th & 12.90 & 6.30 & 8.20 & 8.90 \\
\hline & $\mathrm{Nb}$ & 14.80 & 4.90 & 5.70 & 5.60 \\
\hline & $\mathrm{Pb}$ & 9.2 & 4.2 & 2.3 & 2.3 \\
\hline & $\mathrm{Sr}$ & 121.80 & 39.30 & 54.00 & 54.10 \\
\hline & $\mathrm{Zr}$ & 193.90 & 88.50 & 128.20 & 118.80 \\
\hline & $Y$ & 86.10 & 14.40 & 20.00 & 19.10 \\
\hline \multirow[t]{14}{*}{ ppm } & La & 33.2 & 14.7 & 16.7 & 16.7 \\
\hline & $\mathrm{Ce}$ & 79.1 & 27 & 35 & 35.4 \\
\hline & $\mathrm{Pr}$ & 7.55 & 3.21 & 4.33 & 4.41 \\
\hline & $\mathrm{Nd}$ & 28.5 & 10.9 & 17 & 17.4 \\
\hline & Sm & 7 & 2.2 & 4.1 & 4.3 \\
\hline & $\mathrm{Eu}$ & 1.68 & 0.39 & 0.82 & 0.84 \\
\hline & $\mathrm{Gd}$ & 10.2 & 1.98 & 3.39 & 3.2 \\
\hline & $\mathrm{Tb}$ & 1.69 & 0.31 & 0.57 & 0.59 \\
\hline & Dy & 12.32 & 1.82 & 3.22 & 3.46 \\
\hline & $\mathrm{Ho}$ & 2.47 & 0.49 & 0.67 & 0.67 \\
\hline & $\mathrm{Er}$ & 7.71 & 1.42 & 2.01 & 1.87 \\
\hline & $\mathrm{Tm}$ & 1.13 & 0.28 & 0.33 & 0.31 \\
\hline & $\mathrm{Yb}$ & 7.47 & 1.68 & 2.1 & 2.17 \\
\hline & Lu & 1.04 & 0.25 & 0.27 & 0.3 \\
\hline
\end{tabular}

\section{Possible source regions - red sandstones in Hungary}

There are many sandstone formations on the surface in SW-Hungary, but only a few have red colour - so we have to investigate these formations for the raw material sources.

So far, in the Hungarian archaeological assemblages only a few sandstone artefacts were studied archaeometrically (Palágyi et al. 2006; Piros 2010; Szakmány 1996; Szakmány \& 
Nagy 2005; Szakmány et al. 2008), therefore it is important to give the whole set of information about these formations, as they represent potential raw materials.

\subsection{The Balaton-Highland}

Balatonfelvidék Sandstone Formation (Upper Permian age): Rocks of the Balatonfelvidék Sandstone Formation (a.k.a. "Permian red sandstone”) crop out close to the archaeological site, on the opposite (northern) side of the lake Balaton on the BalatonHighland (see Figure 12) in a $12 \mathrm{~km}$ long, and $5 \mathrm{~km}$ wide area between Zánka and Badacsonyörs, a $22 \mathrm{~km}$ long and maximum $3 \mathrm{~km}$ wide area between Aszófö and Balatonfüzfö, and in some small places near Gyulakeszi, Hidegkút and Litér (Csernussi 1984; Fülöp 1990; Majoros 1963; 1998).

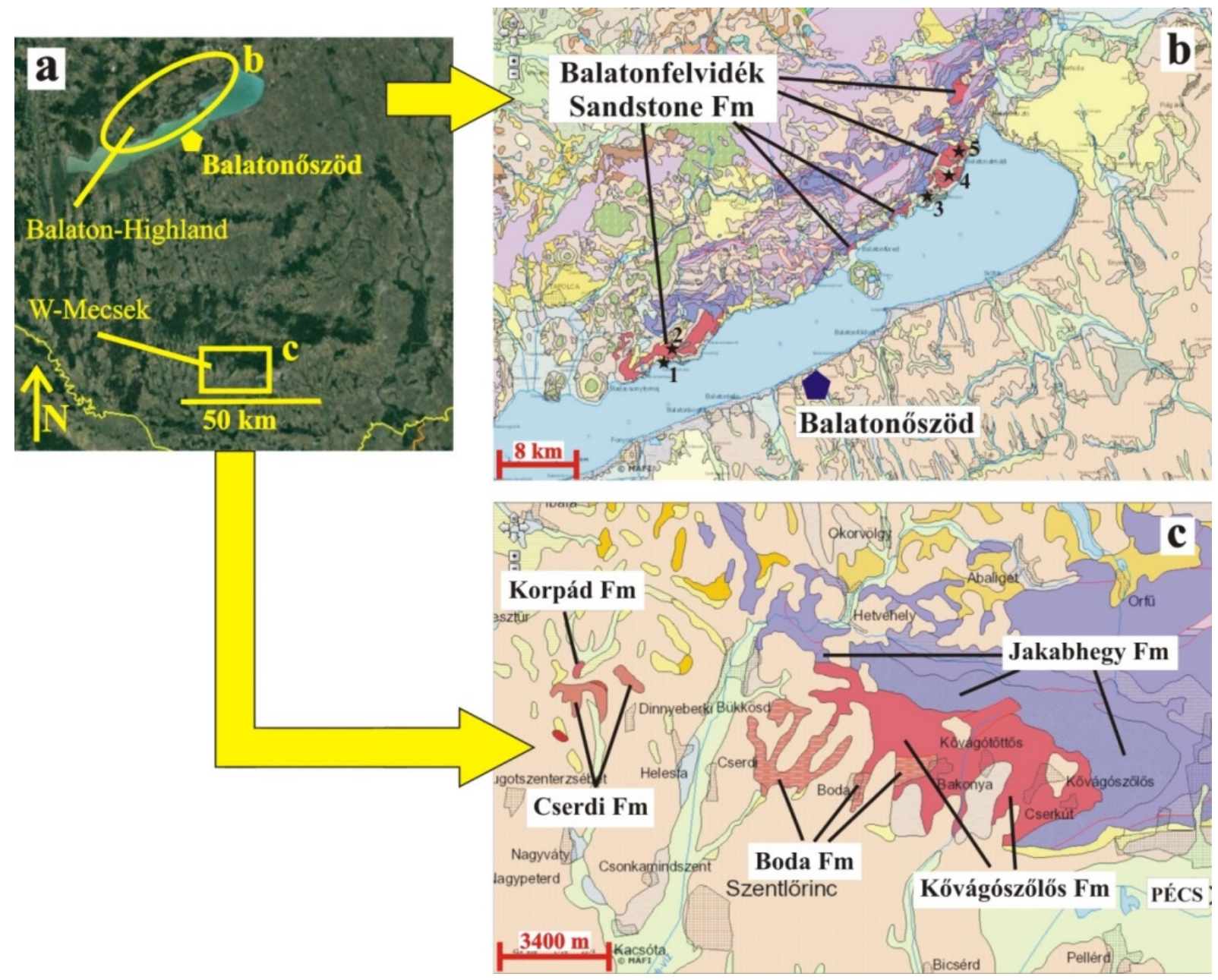

Figure 12. a) Map of SW-Hungary with the archaeological site (original satellite picture by Goole Earth). b)-c) Geological map (Budai \& Gyalog 2010), modified: outcrops of the red sandstone formations of Hungary. Black stars indicate the sampling points of the Balatonfelvidék Sandstone Formation: 1. Pálköve, 2. Balatonrendes, 3. Alsóörs, 4. Köcsi-tó, 5. Balatonalmádi.

This Permian age fluvial sequence consists of three members. The lower member (Paloznak Phanglomerate Member) is a sporadically red coloured, coarse-grained, polymict breccia which originated from semiarid climate talus cones. On the basis of the formation, the Badacsonyörs Conglomerate Member is prevalent, with pebbles and gravels originating from the Balaton Phyllite Formation-Group (the siltstone-shale pebbles and sandstone-shale 
pebbles) and from the Kékkút Dacite Formation (the red and grey pebbles), and a few siliceous shale-, limestone-, gneiss-pebbles.

The most prevalent member is the Red Sandstone and Siltstone Member: an alternation of red sandstone and siltstone, with frequent intercalations of intraformational conglomerate beds. Grey coloured sandstone occurs on the fringe territories of the formation and the lower parts of the member, and in some intraformational conglomerate beds (Csernussi 1984; Fülöp 1990; Majoros 1963; 1998).

The grain size of the siltstones, sandstones and conglomerates varies between $0.005 \mathrm{~mm}$ and 30 cm (Csernussi 1984; Fülöp 1990; Majoros 1963; 1998).

The proportion of the clastic constituents is monotonic: dominant phases are quartz and rock fragments, micas (muscovite, biotite), and "more or less, or zero amount of feldspars" (Fülöp 1990). Among the rock fragments Lower Palaeozoic siltstone, sandstone and metamorphozed acidic volcanic rock fragments occur, together with dacite from the Kékkút Dacite Formation. Quartz-phyllite and gneiss are also present, but only in small quantities. Intraformational siltstone- and dolomite-fragments are also detectable (Csernussi 1984; Fülöp 1990; Majoros 1963; 1998).

The amount of feldspars is less than 20\% (acidic plagioclase, infrequently orthoclase and microcline), the feldspars are frequently sericitizated, and infrequently kaolinizated (Csernussi 1984; Fülöp 1990; Majoros 1963; 1998).

Micas are regularly present: muscovite and discoloured, chloritized biotite.

Illite and kaolinite are the most frequent clay minerals (Fülöp 1990).

The cementation is most frequently sericitic or illitic with a dispersed distribution of hematite (and a subordinate amount of gypsum, anhydrite or magnesite displacing sericite). Hematite often occurs as a crust on the clastic grains too. On the basin margins, in the mature sandstones, the cement is composed of microcrystalline quartz together with kaolinite and dispersed hematite. Infrequently dolomite, gypsum, anhydrite and magnesite occur as independent cement material (Fülöp 1990).

The sandstones of the Balatonfelvidék Sandstone Formation can be divided into two lithological facies types. The dominant facies type is a poorly matured sandstone with bimodal grain-size distribution, quartz, rock fragments and feldspar as clastic constituents and with an illitic-sericitic (or dolomitic) matrix (Fülöp 1990).

The second facies type is a specific feature of the southern Balaton-Highland's fringe territories and of the northern Balaton-Highland, on the lower parts of the formation. It is a mature sandstone type with unimodal grain-size distribution, the clastic constituents are quartz and rock fragments (feldspars are almost absent). The cementation is microcrystalline quartz with kaolinite (Fülöp 1990).

Primary porosity usually vanished by compaction in all types (Csernussi 1984).

Grey (discoloured) medium- and coarse-grained variants are present in the south-western part of the area of the formation (and in a local development at the Hajógyári quarry at Balatonfüred). At the Örsi-hill (near Badacsonyörs, also in the south-western part of the area) crops out a sequence of on the upper side red and on the lower side grey siltstone and sandstone bands, between the lower grey, medium- and coarse-grained sandstone bands and the upper red, fine-grained sandstone bands (Csernussi 1984).

Green-coloured (chloritized) and white-coloured (dolomite-cemented) variants also occur in lenses of several meters (Csernussi 1984).

\subsection{The Western Mecsek mountains}

Permian - Lower Triassic clastic sequences of red conglomerates, sandstones and siltstones are typical in the Western Mecsek mountains, with a wide surface area (see Figure 
12c) and a remarkable thickness (a few thousand metres): the Upper Permian Korpád, Cserdi and Boda Formations and the Upper Permian to Lower Triassic Kövágószőlős and Jakabhegy Sandstone Formations (Figure 12).

The oldest - Lower Permian - Korpád Sandstone Formation is mostly known from drilling cores with a thickness of $100-700 \mathrm{~m}$ and with a few surface outcrops (Budai \& Gyalog 2010; Gyalog 2005). This formation consists of dominantly red, clastic sediments with a significant refinement in the grain size upwards in the sequence (from conglomerate to sandy siltstone). Most of the grains of the conglomerates and sandstones are quartz, quartzite, metamorphic- and volcanic rock fragments (Barabás \& Barabás-Stuhl 1998).

Feldspars are mostly represented by plagioclases, but the secondary albitization of the Kfeldspar grains cannot be excluded (Varga 2009). Potassium-feldspars and plutonic rock fragments are absent or present only in very small amounts within the clastic constituents (Fazekas 1987). Micas are muscovite and strongly chloritized biotite (Varga 2009).

Among the volcanic rock fragments those with andesitic composition are frequent (sporadically fluidal texture with plagioclase microlithes and opaque minerals). This type is unique in the whole sequence in the Western Mecsek mountains and differs from the acidic volcanic rock fragments which originate from the Lower Permian Gyürüfü Rhyolite Formation (Barabás \& Barabás-Stuhl 1998; Fazekas 1987; Varga 2009). This type of rock fragments is also missing among the studied artefacts.

The Upper Permian Cserdi Formation has a 1000 m average thickness and only a few small outcrops near Gyürüfü, Dinnyeberki, Cserdi and Boda. This fluvial sequence consists of the rhythmical alternation of reddish brown (or brownish red, or purplish red) conglomerates and coarse-grained sandstones together with silty fine-grained sandstones in subordinate quantities, with a significant refinement in the grain size upwards in the sequence (Barabás \& Barabás-Stuhl 1998; Bodor \& Szakmány 2009). The rocks of this formation are usually unsorted, and it is characteristic that the coarse-grained bands have a large amount of matrix (silt and fine-grained sand). Totally unsorted, predominantly fine-grained sandstone is also frequent in the sequence. This type of sandstone consists of unrounded, some mm-sized sand grains or very fine, subangular quartz or feldspar pebbles in various quantities and without any coordination (Barabás \& Barabás-Stuhl 1998). Practically, 100\% of the pebbles of the older beds are volcanic rock fragments: rhyolite, rhyodacite and its pyroclastics and "melarhyolite" (i.e., subvolcanic or dyke rock with rhyolitic composition and microgranophyric texture). Moving upwards in the sequence, metamorphic rock fragments occur in progressively larger quantities. The K-feldspar and plagioclase content is significant, but the sodium-content of the rock is low due to the intensive decay of the plagioclases. The potassium-content of the rock is high due to the high muscovite-content (Fazekas 1987). The cementation can be silica, sericite, hematite and carbonate, in the drilling cores anhydrite is significant, too (Bodor \& Szakmány 2009; Varga 2009).

The Upper Permian Boda Claystone Formation (formerly Boda Siltstone Formation) crops out on a larger surface, with a maximum of $1000 \mathrm{~m}$ thickness. This formation consists of the alternation of predominantly red, reddish brown, albite-containing siltstone and claystone. At the lower part, it contains greenish grey sandstone, sandy siltstone and claystone intercalations (Varga et al. 2006). The major rock types of the formation are claystone, siltstone, sandstone, albitolite and dolomite. There are many transitional types, too. The sandstone bands are usually intercalations within the very fine-grained bands (Árkai et al. 2000; Barabás \& Barabás-Stuhl 1998; Máthé 1998; Varga et al. 2005; Varga et al. 2006). In its bulk rock chemical composition, the high sodium-content $\left(5-8 \% \mathrm{Na}_{2} \mathrm{O}\right)$ is characteristic (Árkai et al. 2000; Fazekas 1987; Máthé 1998).

The sandstone intercalations are usually red coloured with a shade of brown, grey or green, with a varying grain-size from fine- to coarse-grained. Parallel and cross-bedding 
occurs. These intercalations infrequently contain carbonized plant fossils and grey siltstoneclaystone-pebbles. The clastic grains are usually angular or only slightly subangular. The quantity of the cementation varies. In the medium- and coarse-grained sandstones the cementation is predominantly carbonatic, but in subordinate quantities hematite, illite or sericite, chlorite, albite and silica also occur. Carbonate veins are frequent (Varga et al. 2006).

The sandstones contain 25-40\% feldspars (more plagioclases, less K-feldspars), 20-30\% quartz (monocrystalline and polycrystalline quartz), volcanic rock fragments (predominantly grains of recrystallized acidic volcanic groundmass and glass, together with neutral and basic volcanic rock grains) in large quantities, and a few detrital micas (muscovite and chloritized biotite). Metamorphic and sedimentary rock fragments (i.e., resedimented intraformational red siltstone and claystone grains) also occur. Accessory minerals (mostly in the fine-grained sandstones) are magnetite, ilmenite, zircon, monacite, rutile, apatite, tourmaline, titanite, and Cr-spinel (Varga et al. 2006).

The Upper Permian - Lower Triassic Kővágószőlős Sandstone Formation crops out in a larger surface than the Cserdi or Boda Formations with 150 to $1400 \mathrm{~m}$ total thickness. This formation is a fluvial sequence, with the rhythmical alternation of various coloured conglomerate, arkose sandstone, siltstone and claystone bands, with a significant refinement and then a coarsening in the grain size upwards in the sequence (Barabás \& Barabás-Stuhl 1998).

In the beginning of the sedimentation of this formation, large quantities of granitemigmatite-originated clastic fragments (i.e., quartz, K-feldspar and quartz-K-feldspar intergrowths) occur (and the proportion of the metamorphic and volcanic rock fragments decreases). Upwards in the sandstones the amount of quartz is increasing (Fazekas 1987).

Based on the colour, petrographic and sedimentary characteristics, this formation was divided into four members.

The sandstones of The Bakonya Sandstone Member ("variegated sequence”, Császár 1997) are poorly sorted, mainly red (or green, grey, variegated), dominantly coarse-grained sandstones (with significant amounts of fine-grained bands). The fine-grained sediments are granularly disintegrating (poorly consolidated, falling apart to pieces) and contain carbonate concretions.

The Kővágótöttös Sandstone Member ("grey sequence” Császár 1997) only rarely contains red and green bands, with varying grain-sizes (from conglomerates to silty claystones). This member is rich in organic material.

The Cserkút Sandstone Member (“overlying red sandstone” Császár 1997) consists of purplish red or red, dominantly medium-grained sandstones with sporadically occurring pebbles. Conglomerate, fine-grained sandstone and siltstone bands also occur. On the top of this member there is a few meters thick, reddish brown coloured sandstone band with carbonate concretions. This reddish brown sandstone is discoloured at some places.

At the transition part of the Kövágótöttös and Cserkút Members, a uranium ore-bearing "green sandstone bed" was formed.

The sandstones of the Tótvár Sandstone Member ("sandstone with violet gravel” Császár 1997) are crimson, purplish red or light purple coloured, unsorted, coarse-grained sandstones, with frequent pebbles and a silty matrix. The characteristic purple colour is the result of the large amount of rhyolite pebbles and angular rhyolitic rock fragments (Barabás \& BarabásStuhl 1998).

The Jakabhegy Sandstone Formation has the widest distribution on the surface of all the Permian - Lower Triassic clastic sequences in the Western Mecsek mountains. This formation has a thickness between 60 and $380 \mathrm{~m}$. The beds of the formation mainly crop out at the Jakab-hill. The transition between the Kővágószőlős and Jakabhegy Formations is continuous (Fazekas 1987). 
Upwards in the sequence the amount of quartz is rising progressively in the sandstones. In the lower parts of the Jakabhegy Formation, plagioclase is totally missing, while the sodium-content of the rock is decreasing significantly compared to the lower members of the Kövágószőlös Formation. The amount of the potassium-feldspars is more or less the same in the whole sequence, but quartz-K-feldspar intergrowths are almost missing in the Jakabhegy Formation. Among the volcanic rock fragments, mostly various kinds of silicified rhyolite and tuffs are present, but rhyolite-fragments, which originate from the Gyürüfü Rhyolite Formation, also occur as in the above-mentioned older formations. The most mature sandstone is the so-called "sandstone with orientated pebbles", which is a cross-bedded, palered or pale-violet sandstone, appearing in the upper part of the Jakabhegy Formation. Upwards the grain-size decreases and plagioclase-fragments and biotite reappear. The amount of the volcanic-fragments increases as well (Fazekas 1987).

In the whole Jakabhegy Formation the clastic constituents have the same characteristics: the predominant constituent is quartz, and in subordinate amount felsitic rhyolitic groundmass-fragments and K-feldspars are present. Quartz-feldspar intergrowths are very rare. Acidic plagioclase-fragments occur only in small amounts in the western territories of the formation, only in the upper part of the sequence. The less mature beds of the sandstones are micaceous (mainly muscovite, rarely biotite; Fazekas 1989).

The cementation is illitic-sericitic, siliceous or - subordinately - carbonatic (dolomitic, calcitic). In some places the cementation is impregnated with red iron oxides. Thin sulphate intercalations also occur (Fazekas 1989).

\section{Comparison of the raw material of the artefacts and the red sandstone formations}

\subsection{Distribution of the framework grains (quartz-feldspar-rock fragments) - comparison}

Beside the average distribution-data of the artefacts, Figure 13 shows the representative distribution-data of the Balatonfelvidék Sandstone Formation (matured and unmatured sandstone types, Csernussi 1984; Fülöp 1990; Majoros 1998), as well as the average distribution-data of the Permian - Lower Triassic age sandstones form the Western Mecsek mountains (Fazekas 1987; 1989). Data on the precise distribution of the Boda Formation are currently missing.

Subgroup I/1 and I/2 of the archaeological finds are lithic arenites (litharenites) and sublitharenites. Their composition lies in the field of the matured variant of the Balatonfelvidék Sandstone Formation.

Group II has a transitional composition between subarkoses and sublitharenites very near to the average composition of the Jakabhegy Sandstone Formation.

The other formations of the Mecsek mountains display a higher feldspar- and rockfragment-content and less quartz.

\subsection{Bulk rock chemistry - comparison}

The major-, trace- and RE-element patterns of the finds (see Table 1) have been compared with the data of all the above mentioned formations (Balaton-Highland: data of recently gathered red sandstone samples (Tables 2-4, sampling locations see Figure 12) and data from Csernussi 1984; Western Mecsek mountains: data of the sandstones and siltstones from drilling cores from Varga (2009) (Figures 14-25).

Figures 14-21 show the major-element composition of the sandstone formations (one after another) compared with the artefacts. Figures 22-23 show the trace-element patterns and 
Figures 24-25 show the RE-element patterns of the two sandstone formations that fit the major-element composition of the artefacts at most.
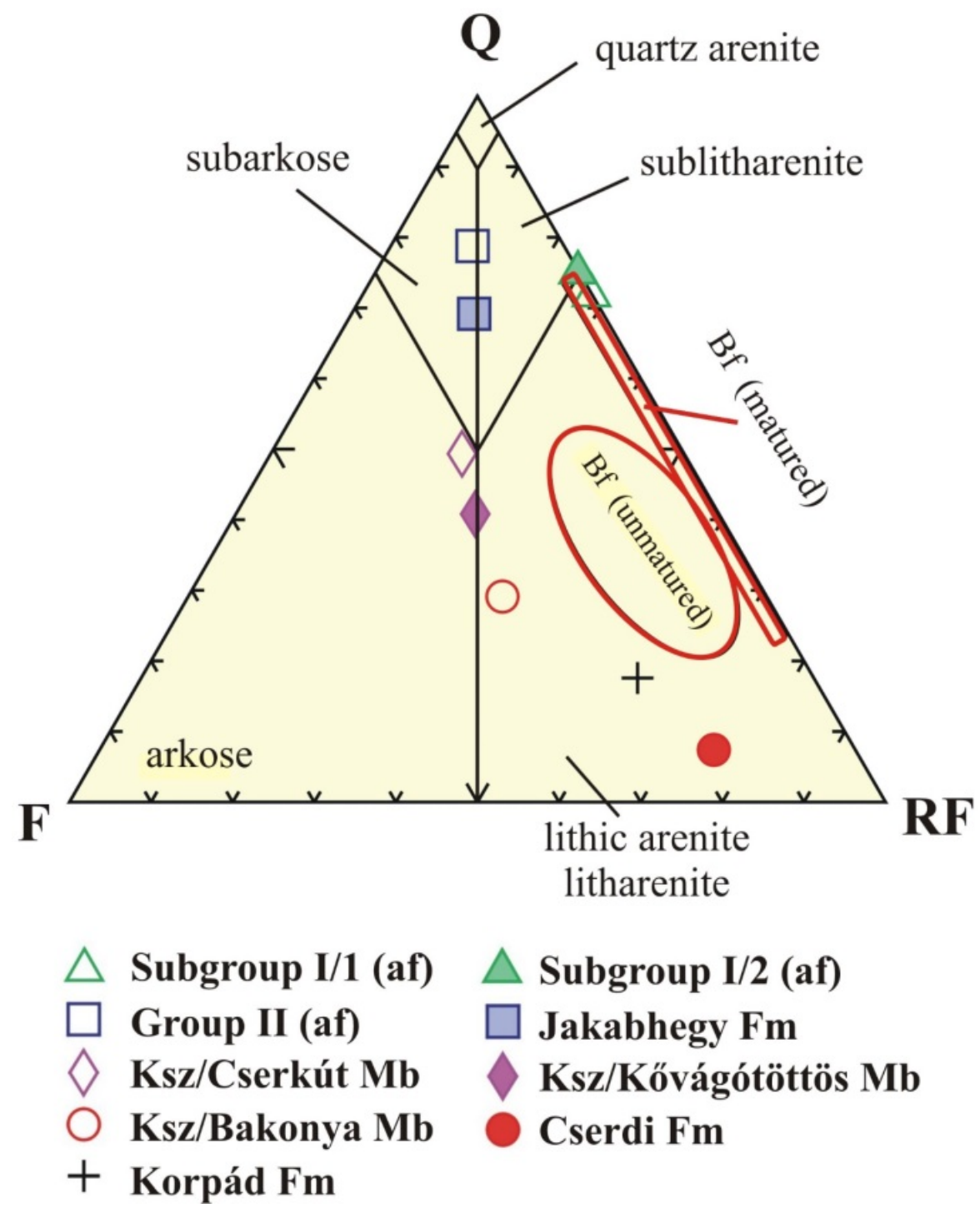

Figure 13. Distribution of the framework grains (in quartz-feldspar-rock fragments - QFR - triangular diagram): average values of the artefacts (af) and the "red” sandstones from the Western Mecsek mountains and areas of representative data of the matured and unmatured sandstones of the Balatonfelvidék Formation (Bf). Members $(\mathrm{Mb})$ of the Kővágószőlős Formation (Ksz) are presented separately on the figure.

\subsubsection{Major element patterns - comparison}

The major element patterns of the comparative samples of the Balatonfelvidék Sandstone Formation (Figure 14) - similarly to the artefacts - show less sodium-, calcium- and magnesium-content than the values of the Upper Continental Crust (UCC) by Taylor \& McLennan (1985) and McLennan (2001), with the exception of one older data-set from Csernussi (1984). They show a slightly higher silica-content. They have various iron-, alumina-, titanium-, potassium- and manganese-contents. 


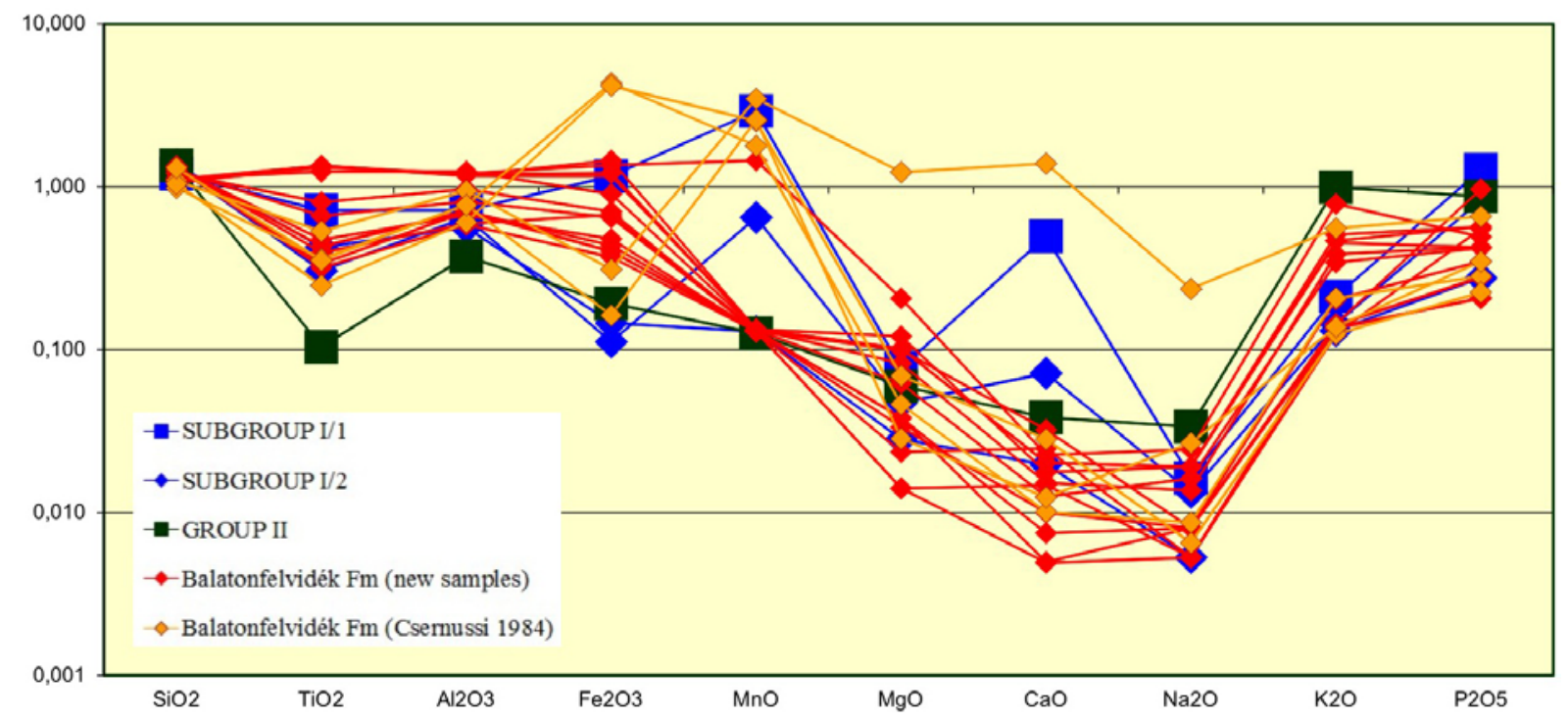

Figure 14. Balatonfelvidék Sandstone Formation and artefacts: UCC normalized major element patterns. UCCvalues by Taylor \& McLennan (1985); McLennan (2001).

The major element composition of Group I artefacts fits well within the composition range of the Balatonfelvidék Sandstone Formation. Group II artefacts have a bit differing composition: lower titanium-, higher potassium and sodium-content.

The sodium- and magnesium-content of the formations of the Western Mecsek mountains (Figures 15-21) are significantly higher than in the measured artefacts, with the exception of the Jakabhegy Sandstone Formation (and one sample of the Korpád Sandstone Formation). Nevertheless, the Korpád Sandstone Formation can be excluded from the possible sources because of the composition and distribution of the clastic grains. The potassium-content of the Mecsek samples is near to the potassium-content of Group II artefacts, i.e., significantly higher than the potassium-content of Group I. So, the major element composition of Group II artefacts fits most within the composition range of the Jakabhegy Sandstone Formation.

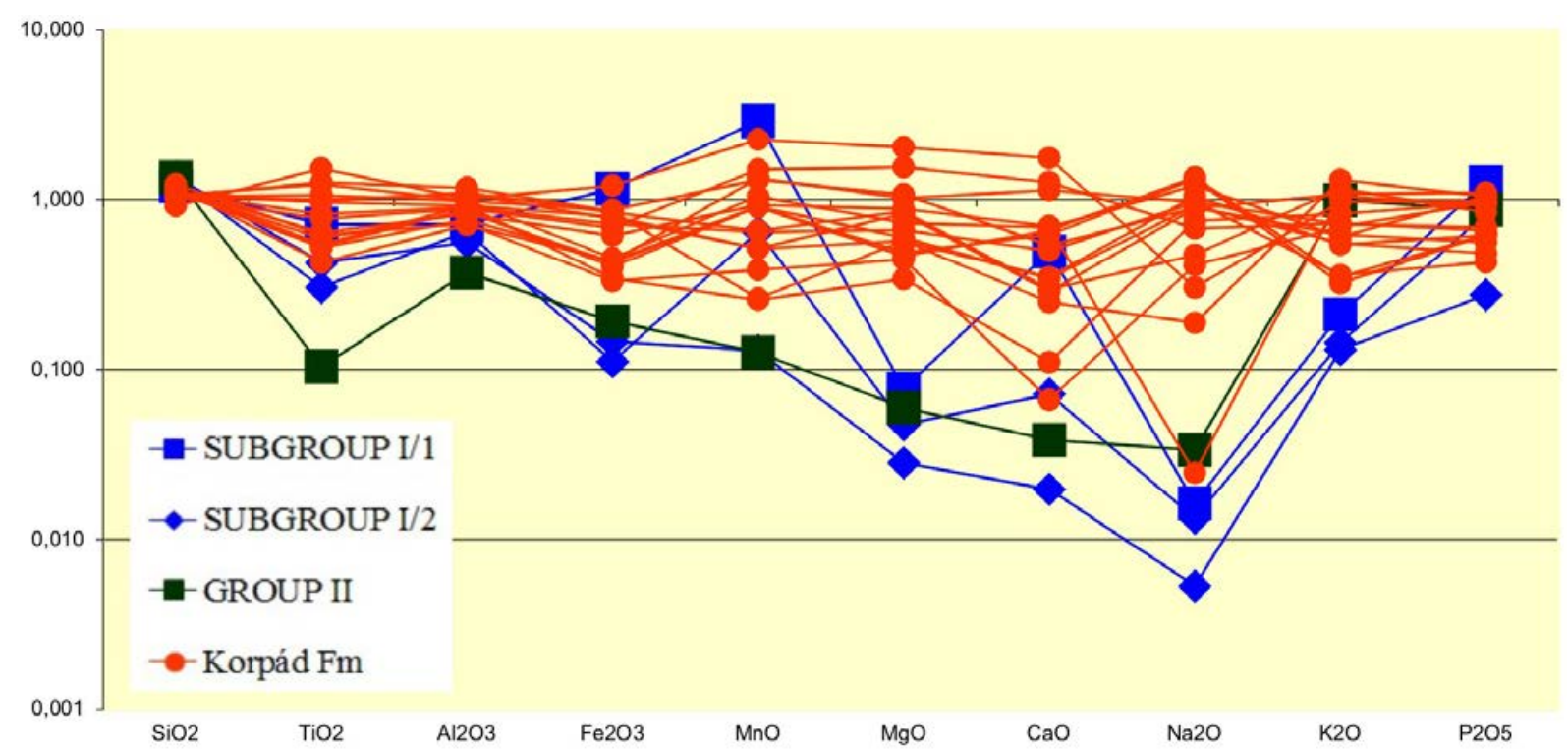

Figure 15. Western Mecsek mountains, Korpád Sandstone Formation and artefacts: UCC normalized major element patterns. UCC-values by Taylor \& McLennan (1985); McLennan (2001). 


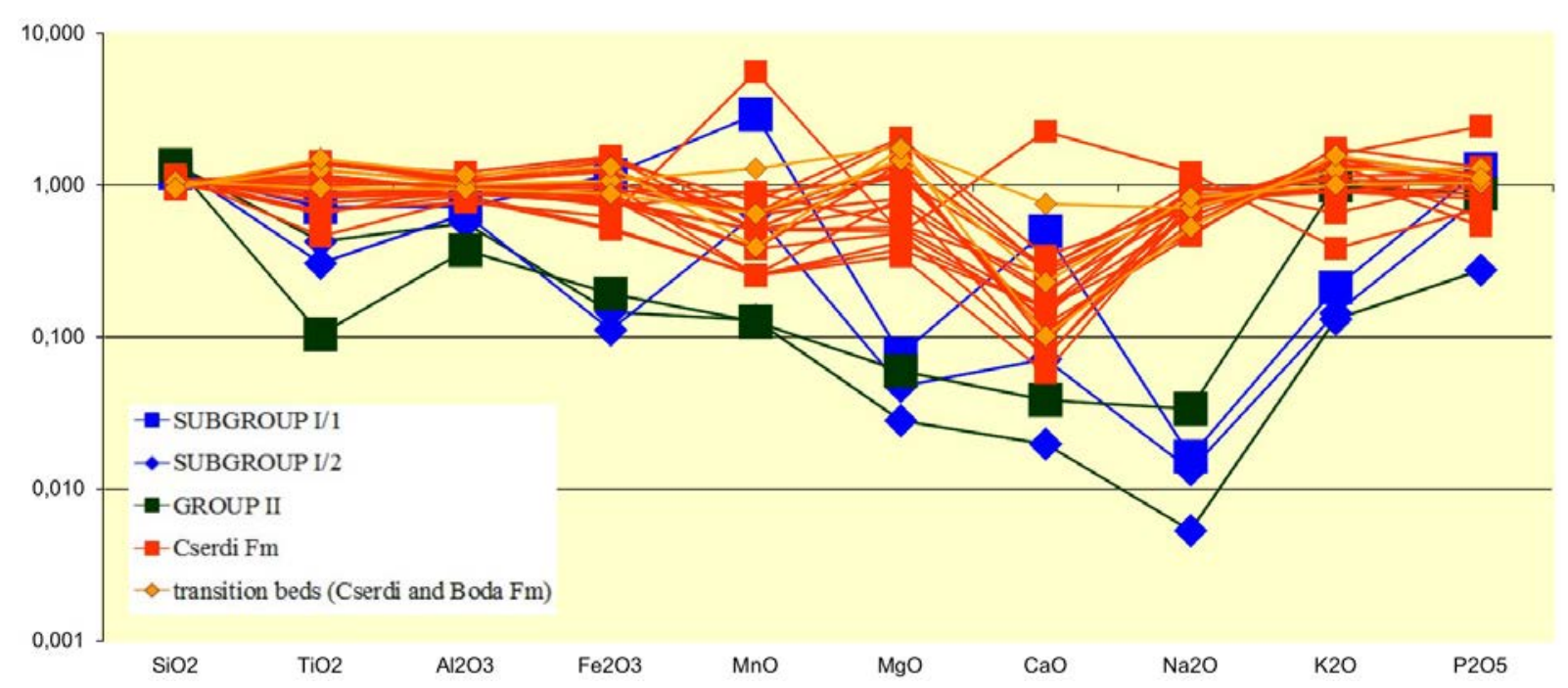

Figure 16. Western Mecsek mountains, Cserdi Formation, transition bands between Cserdi and Boda Formations and artefacts: UCC normalized major element patterns. UCC-values by Taylor \& McLennan (1985); McLennan (2001).

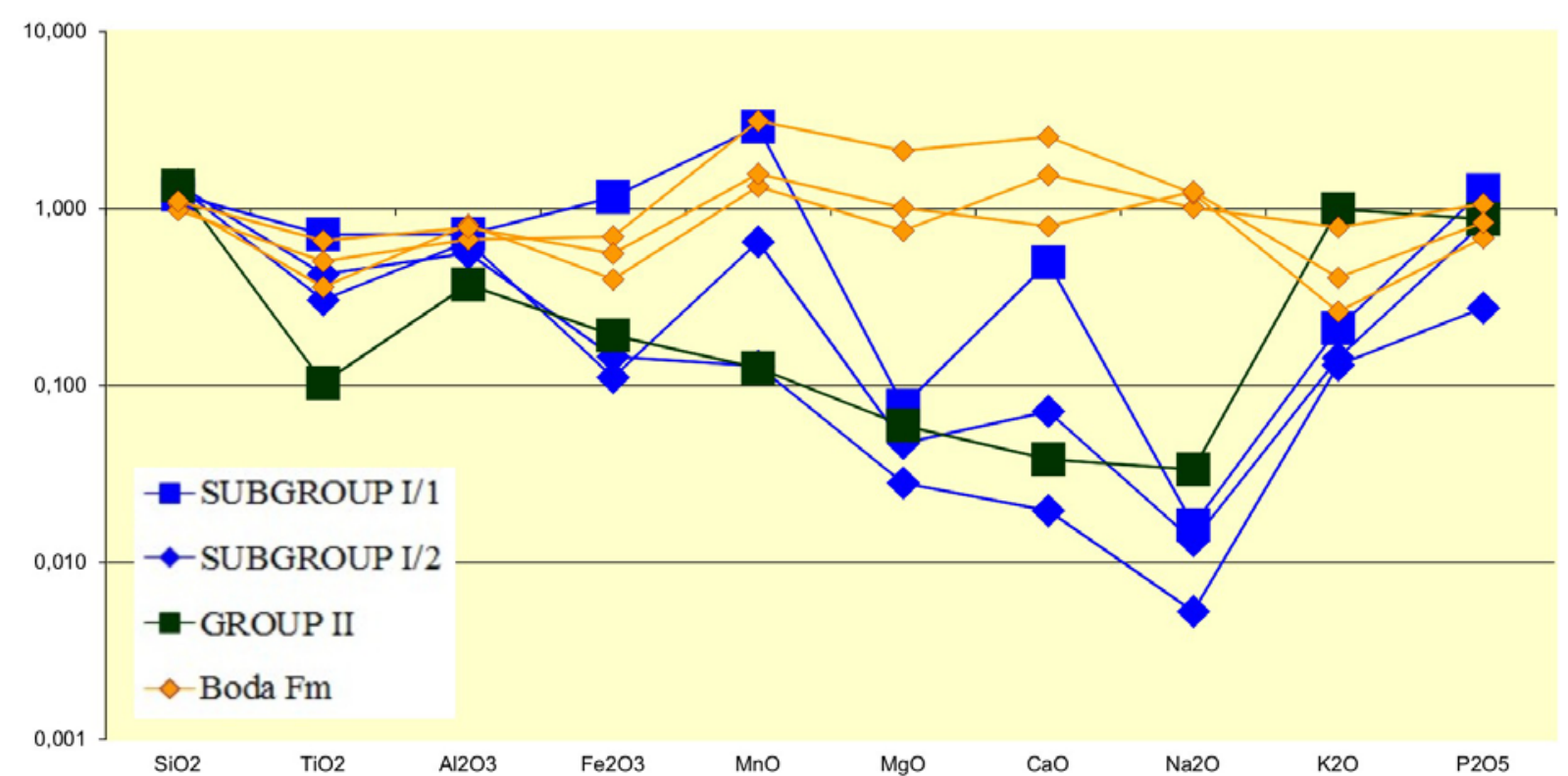

Figure 17. Western Mecsek mountains, Boda Claystone Formation and artefacts: UCC normalized major element patterns. UCC-values by Taylor \& McLennan (1985); McLennan (2001). 


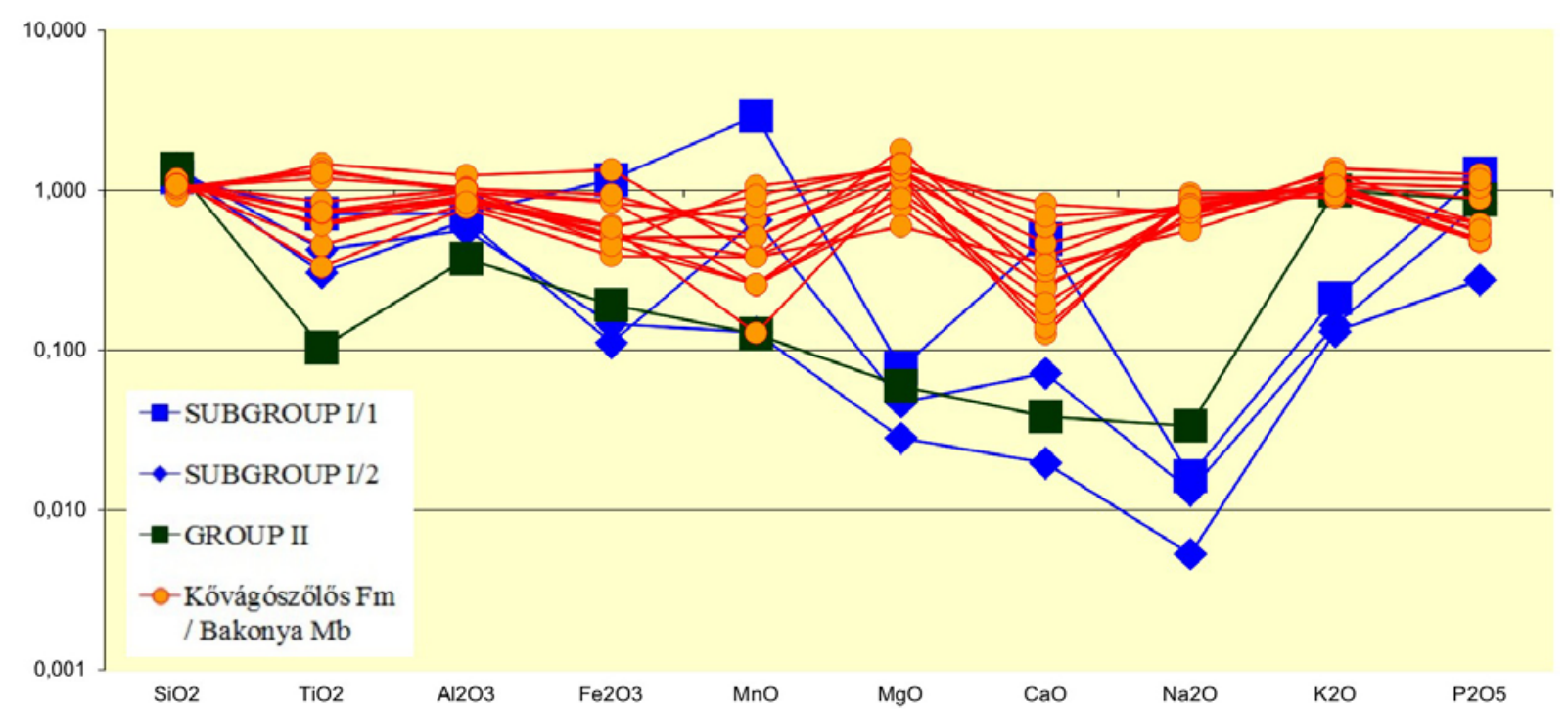

Figure 18. Western Mecsek mountains, Kővágószőlős Sandstone Formation, Bakonya Sandstone Member and artefacts: UCC normalized major element patterns. UCC-values by Taylor \& McLennan (1985); McLennan (2001).

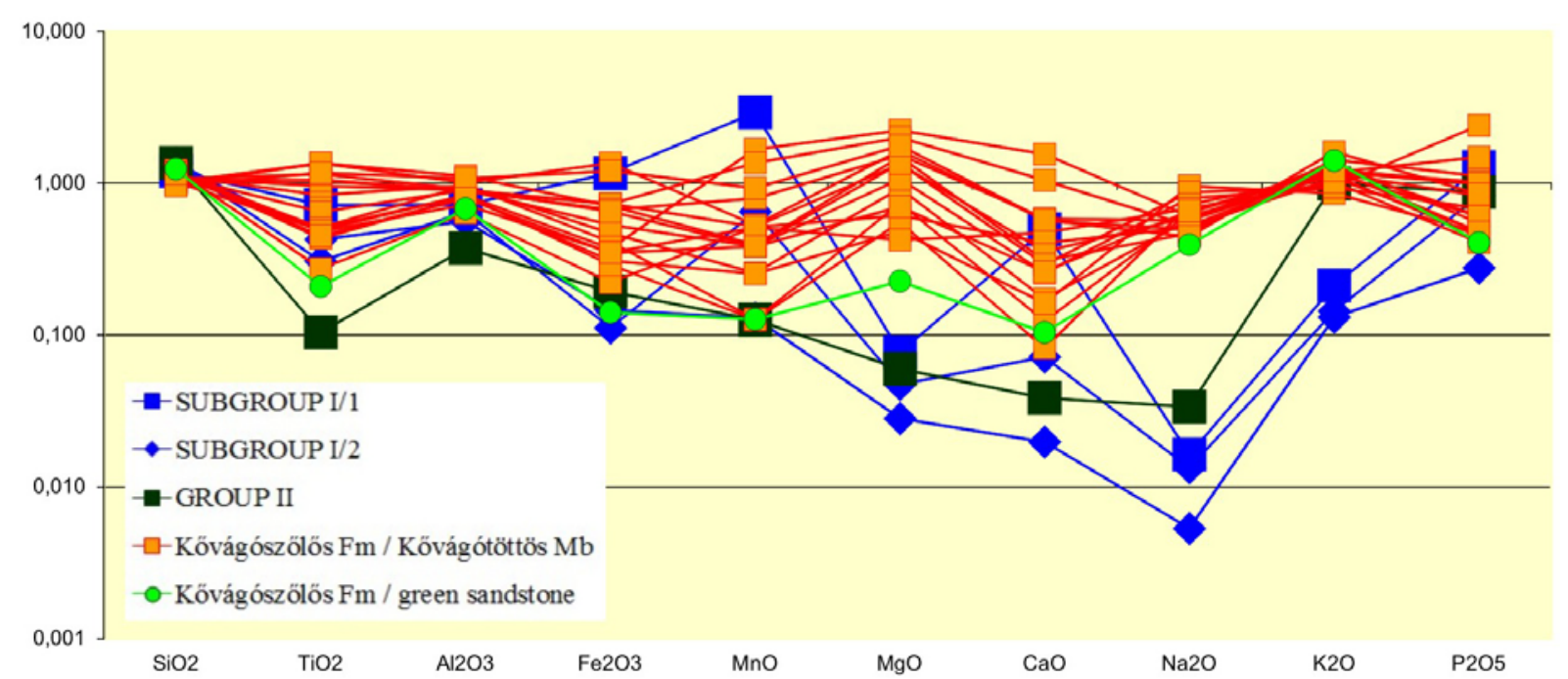

Figure 19. Western Mecsek mountains, Kővágószőlős Sandstone Formation, Kővágótöttös Sandstone Member, "green sandstone” and artefacts: UCC normalized major element patterns. UCC-values by Taylor \& McLennan (1985); McLennan (2001). 


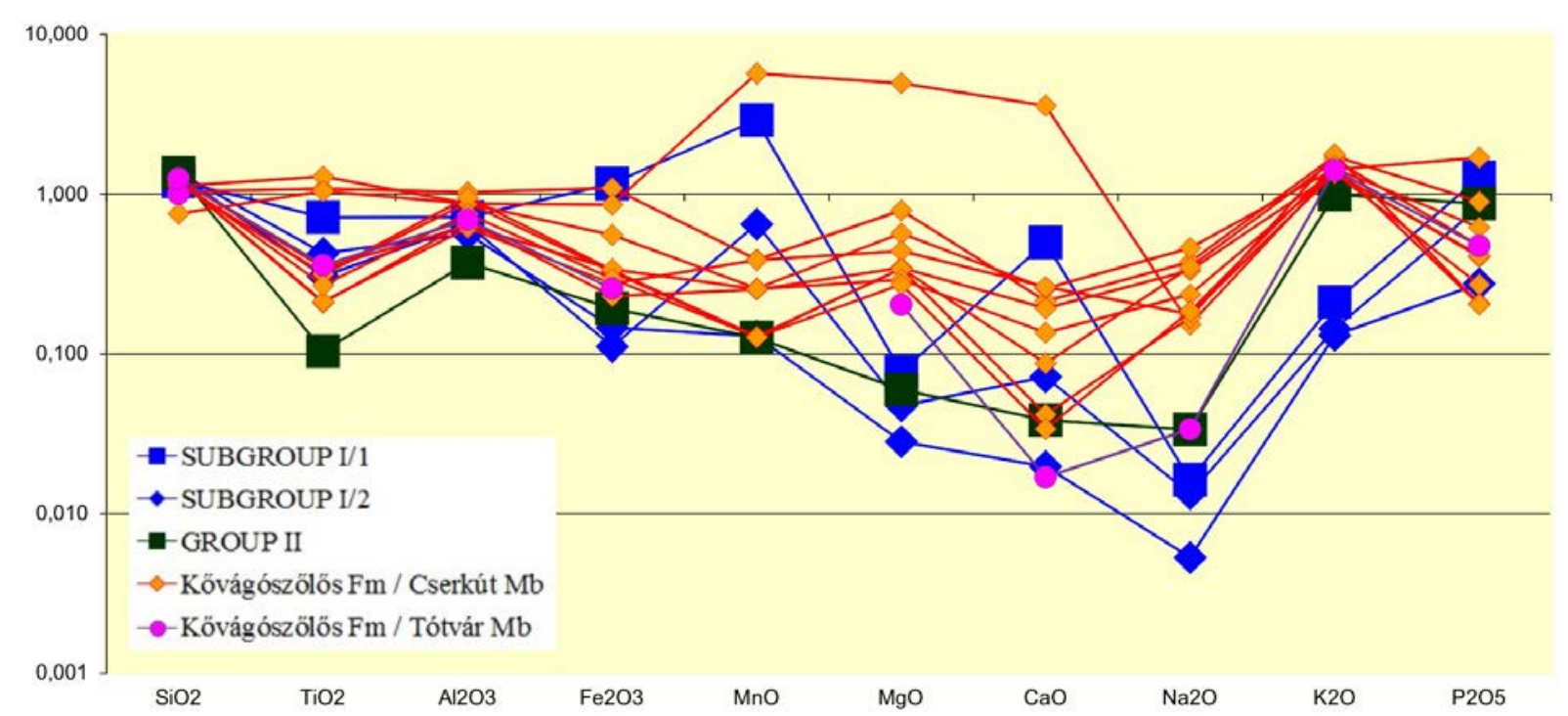

Figure 20. Western Mecsek mountains, Kővágószőlős Sandstone Formation, Cserkút Sandstone Member, Tótvár Sandstone Member and artefacts: UCC normalized major element patterns. UCC-values by Taylor \& McLennan (1985); McLennan (2001).

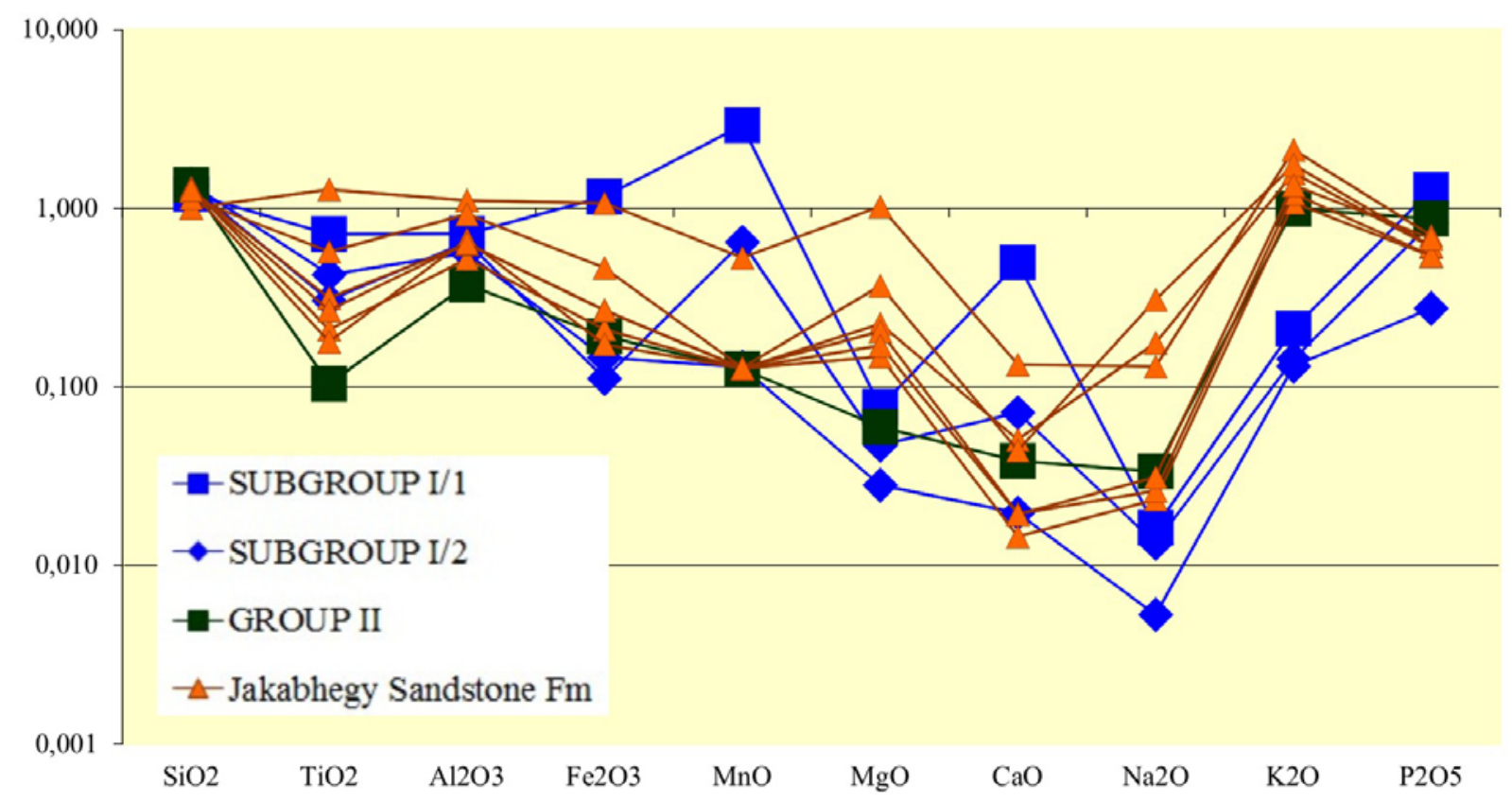

Figure 21. Western Mecsek mountains, Jakabhegy Sandstone Formation and artefacts: UCC normalized major element patterns. UCC-values by Taylor \& McLennan (1985); McLennan (2001).

\subsubsection{Minor and REE patterns - comparison}

The minor element patterns of the sandstones and siltstones of the Balatonfelvidék and the Jakabhegy Formation are various within both formations, nevertheless the minor element patterns of Group I artefacts fits better with the patterns of the Balatonfelvidék Formation (Figure 22), while the patterns of Group II artefacts fits more with the Jakabhegy Formation (Figure 23). In the second case the fitting is not as good as in the case of Group I. 


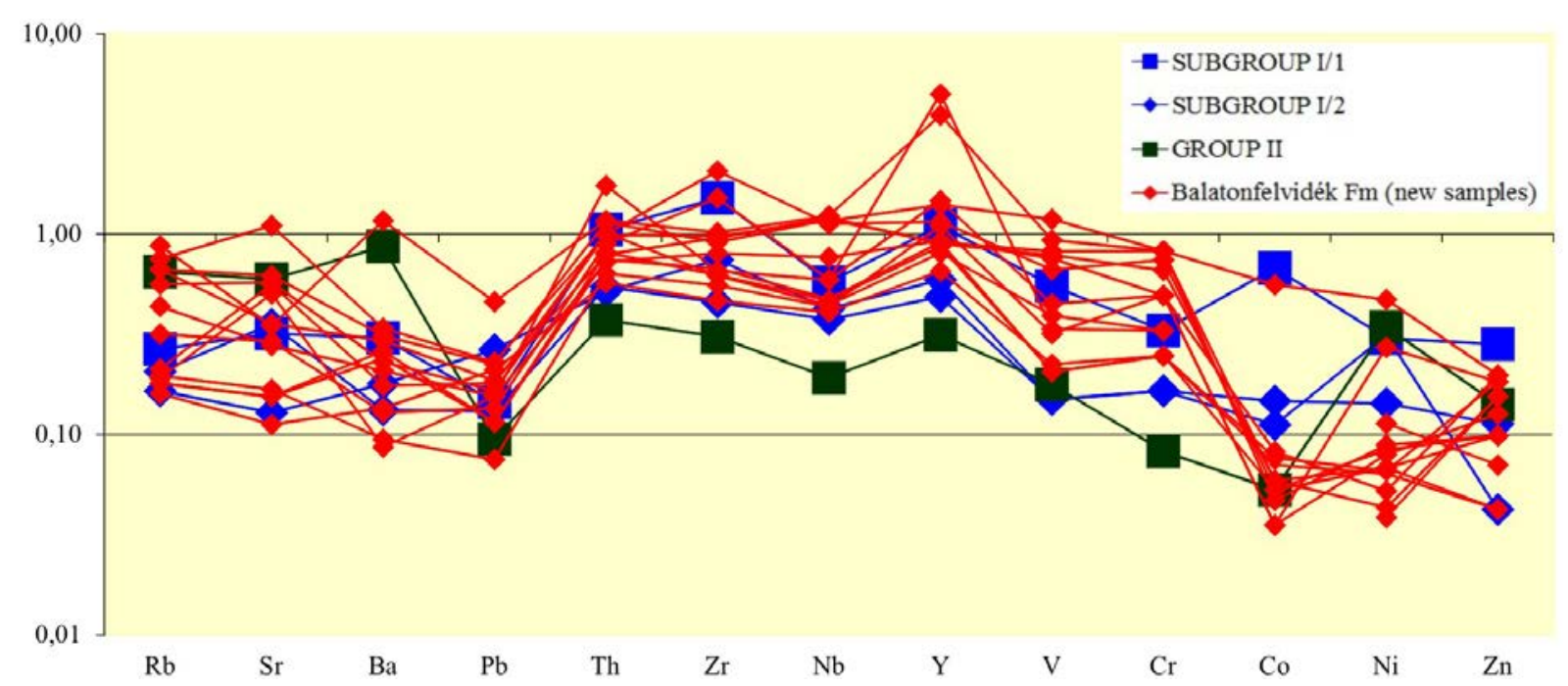

Figure 22. Balatonfelvidék Sandstone Formation and artefacts: UCC normalized trace element patterns. UCCvalues by Taylor \& McLennan (1985); McLennan (2001).

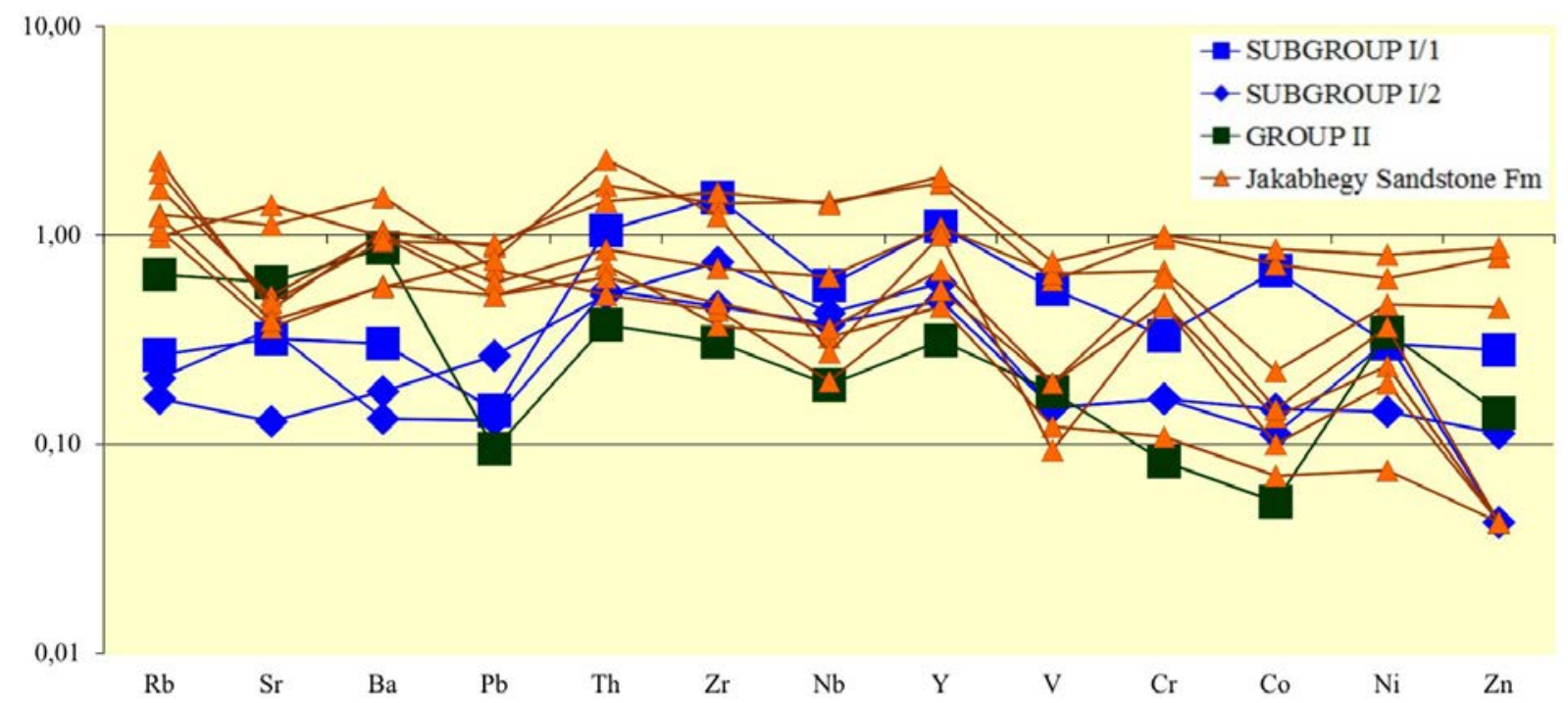

Figure 23. Western Mecsek mountains, Jakabhegy Sandstone Formation and artefacts: UCC normalized trace element patterns. UCC-values by Taylor \& McLennan (1985); McLennan (2001).

The rare earth element content of the sandstones of the Balatonfelvidék Formation (Figure 24) has greater variability than the REE-content of the sandstones and siltstones of the Jakabhegy Formation (Figure 25). The REE patterns of Subgroup I/1 of the artefacts fits better to the patterns of the Balatonfelvidék Formation, while the patterns of Group II artefacts fits better to the Jakabhegy Formation. The REE patterns of Subgroup I/2 of the artefacts (the discoloured ones) lie between the other groups (Compare Figures 24-25). 


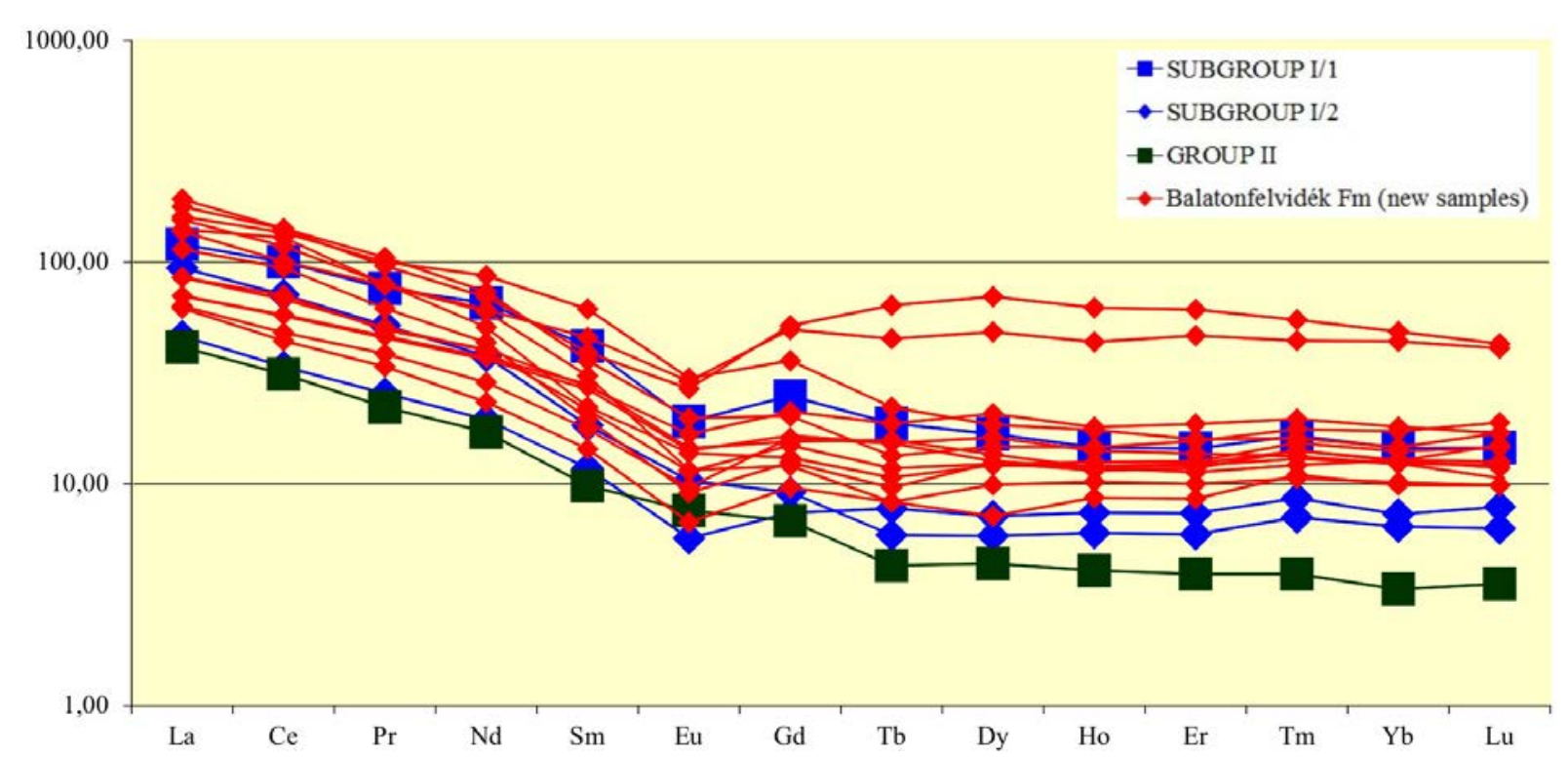

Figure 24. Balatonfelvidék Sandstone Formation and artefacts: chondrite normalized rare earth element patterns. Chondrite-values by Sun \& McDonough (1989).

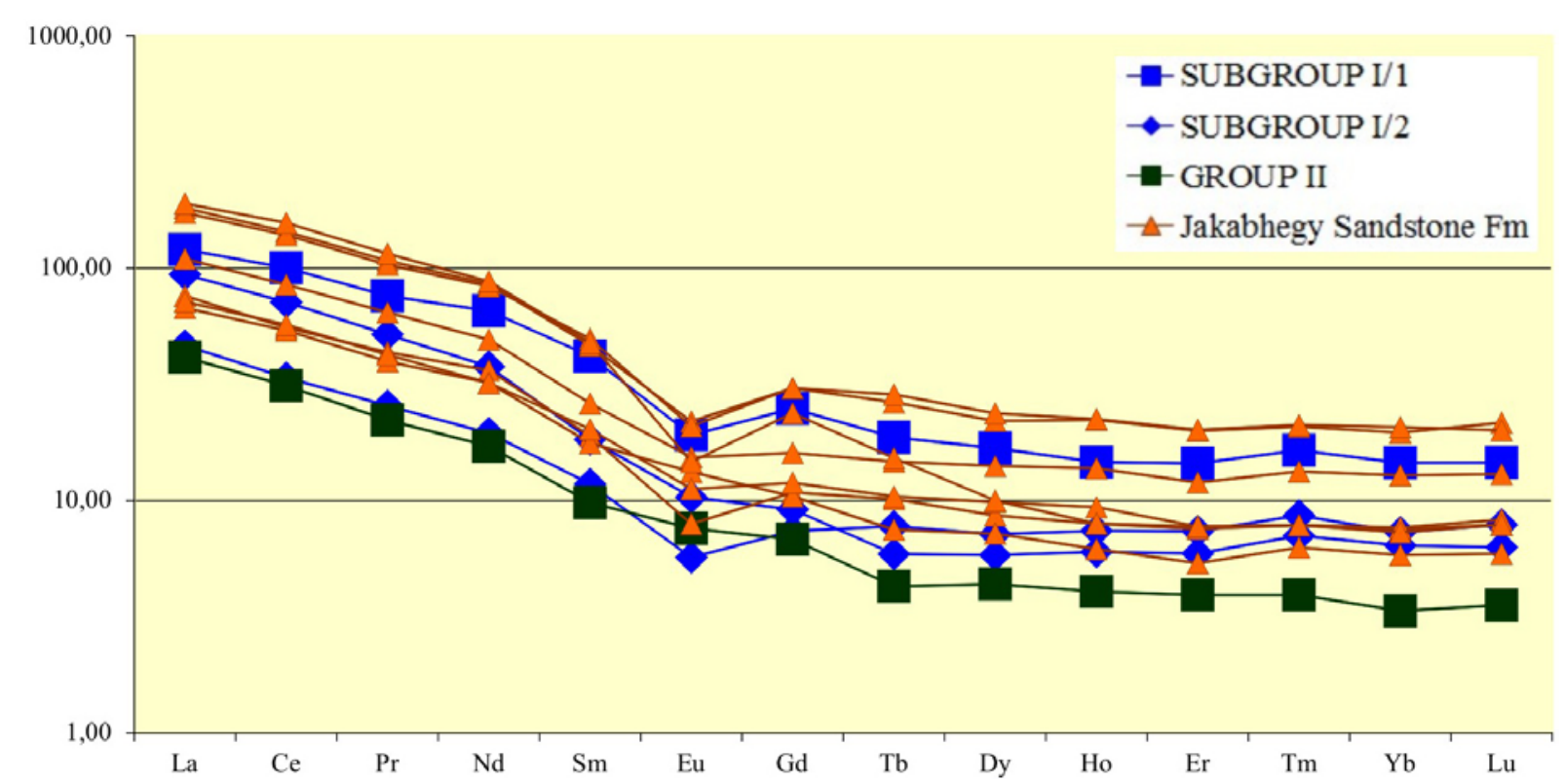

Figure 25. Western Mecsek mountains, Jakabhegy Sandstone Formation and artefacts: chondrite normalized rare earth element patterns. Chondrite-values by Sun \& McDonough (1989).

\section{Discussion and conclusions}

Based on the results of the above investigations and the comparative data of the possible source rocks the most probable origin of the raw material of the artefacts can be selected.

The red sandstones of the Western Mecsek mountains - except the Jakabhegy Sandstone Formation - can be excluded from the possible sources, primarily because of the high potassium-feldspar content, and because of their sodium- and magnesium-content, which is significantly higher than the sodium- and magnesium-content of the artefacts.

Other disqualifying petrographic characteristics of the following Formations from the Western Mecsek mountains are:

The Korpád Sandstone Formation can be excluded from the possible sources because the amount of the rock-fragments within the framework grains is much higher than in the 
artefacts (see Figure 13), and among these rock fragments is a unique andesitic rock fragment type (with a characteristic appearance). This rock fragment type is not present in the raw material of the artefacts.

The Cserdi Formation can be excluded because of the amount of the rock-fragments within the framework grains, which is much higher than in the artefacts (see Figure 13), the high plagioclase content, the poor sorting of the rocks and the much larger amount of matrix compared to the raw material of the artefacts.

The Bakonya Sandstone Member of the Kövágószőlös Sandstone Formation can be excluded because of the poor sorting of the rocks and the poor consolidation of the finegrained sediments - these types are granularly disintegrating (falling apart to pieces), and therefore not useful as raw material.

The Kővágótöttös Sandstone Member of the Kővágószőlős Sandstone Formation can be excluded because of the high amount of organic material, which is not present in the artefacts analysed so far.

The Cserkút Sandstone Member of the Kővágószőlős Sandstone Formation can be excluded because of the amount of feldspars, which is too large in comparison to the artefacts.

The Tótvár Sandstone Member of the Kővágószőlös Sandstone Formation can be excluded because of the poor sorting of the rocks and the number of rhyolite-fragments, which is too large in comparison to the artefacts.

The artefacts of Group I are very similar - in the appearance of the respective components and the proportion of the framework grains (see Figure 13) and in its chemical composition (see Figure 14) - to the sandstones of the Red Sandstone and Siltstone Member of the Balatonfelvidék Sandstone Formation, and here primarily to the second facies type. This type is a mature sandstone, almost void of feldspar (litharenite), in which quartz and rock fragments are predominant among the clastic grains. This facies type is characteristic of the confines of the Southern Balaton Highland and the lower part of the Balatonfelvidék Sandstone Formation in the Northern Balaton Highland (see Figure 12).

The artefacts of Group II are very similar - in the appearance of the respective components and the proportion of the framework grains (see Figure 13), as well as in its chemical composition (see Figure 21) - to the red sandstones of the Jakabhegy Sandstone Formation, especially to the higher levels of the formation, where the number of volcanic rock fragments and micas increase and plagioclase is sporadically present (see Figure 12).

The distribution of the red sandstone raw materials corresponds well to the trend that the people of the Balatonőszöd - Temetöi dülö site made their tools mainly from local raw materials, e.g., basalt and basaltic lapilli tuff from the Balaton-Highland (Péterdi 2011; Péterdi et al. 2011; 2014a). The raw material of some tools, however, originates from regional sources (from a distance of more than $30 \mathrm{~km}$ ), e.g., from alkaline basic rocks ("trachydolerites") and a white, andalusite-bearing two-mica granite from the Mecsek mountains (Péterdi 2011). On the site, only a few polished stone artefacts were found made of raw material from distant sources (more than $200 \mathrm{~km}$ ), e.g., from nephrite and serpentinite from Lower Silesia (Poland), and a contact metabasite from the Krkonoše-Jizera Crystalline Unit (Czech Republic; Péterdi 2011; Péterdi et al. 2014b).

\section{Acknowledgements}

The author would like to thank Tünde Horváth, leading archaeologist of the excavations at Balatonőszöd - Temetöi dülö archaeological site, for offering me the opportunity to study the excavated stone tools; Katalin T. Biró and the reviewers for helping to improve the scientific value and the English language of the text; and the National Research, Development 
and Innovation Fund NKFIH Grant No. K 62874 and K 100385 for financial support for the analyses.

\section{References}

Árkai, P., Balogh, K., Demény, A., Fórizs, I., Nagy, G. \& Máthé, Z. 2000, Composition, diagenetic and post-diagenetic alterations of a possible radioactive waste repository site: the Boda Albitic Claystone Formation, southern Hungary. Acta Geologica Hungarica, 43(4): 351-378. URL: http://real-j.mtak.hu/2996/1/ActaGeologica_43.pdf

Barabás, A. \& Barabás-Stuhl, Á. 1998, A Mecsek és környezete perm képződményeinek rétegtana. In: Magyarország geológiai képződményeinek rétegtana (Bérczi, I. \& Jámbor, Á., Eds.), MOL Rt. - Magyar Állami Földtani Intézet, Budapest: p. 187-215. (in Hungarian) ("Stratigraphy of the Permian Age formations of the Mecsek Mts. and its vicinity")

Bodor, S. \& Szakmány, Gy. 2009, A felső-permi Cserdi Konglomerátum Formáció kavicsanyagának kőzettani és geokémiai vizsgálati eredményei (XV. Szerkezetkutató fúrás, Ny-Mecsek). Földtani Közlöny, 139(4): 325-340. (in Hungarian) ("Petrology and geochemistry of the gravels of the Upper Permian Cserdi Conglomerate Formation (borehole No. XV, W Mecsek Mts)")

URL:http://epa.oszk.hu/01600/01635/00330/pdf/EPA01635_foldtani_kozlony_2009_13 9_4_325-340.pdf

Budai, T. \& Gyalog, L. (Eds.) 2010, Magyarország földtani atlasza országjáróknak. Geological Map of Hungary for Tourists. Magyar Állami Földtani Intézet, Budapest, 276 p. (in Hungarian and in English)

Chayes, F. 1956, Petrographic modal analysis. An elementary statistical appraisal. Wiley, New York, 113 p.

Császár, G. (Ed.) 1997, Basic litostrarigraphic units of Hungary. Charts and short descriptions. Product of the Subcommissions of the Stratigraphic Commission of Hungary, Budapest, $114 \mathrm{p}$.

Csernussi, G. 1984, Litofáciesvizsgálatok a “Balatonfelvidéki Vörös Homokkö Formáció”ban. Master's thesis at the Department of Petrology and Geochemistry (Faculty of Sciences), Eötvös Loránd University, Budapest, 127 p. (in Hungarian) (“Lithofacies studies in the 'Balatonfelvidék Red Sandstone Formation'”)

Dickinson, W.R. 1970, Interpreting detrital modes of graywacke and arkose. Journal of Sedimentary Petrology, 40: 695-707. doi:10.1306/74D72018-2B21-11D78648000102C1865D

Dickinson, W.R. \& Suczek, C.A. 1979, Plate tectonics and sandstone compositions. AAPG Bulletin, 63: 2164-2182. doi:10.1306/2F9188FB-16CE-11D7-8645000102C1865D

Fazekas, V. 1987, A mecseki perm és alsótriász korú törmelékes formációk ásványos összetétele. Földtani Közlöny, 117: 11-30. (in Hungarian) ("Mineralogical composition of Permian and Lower Triassic elastics from the Mecsek Mts")

URL: http://epa.oszk.hu/01600/01635/00254/pdf/EPA01635_foldtani_kozlony_1987_1 17_1_11_30.pdf 
Fazekas, V. 1989, Ásvány-kőzettani megfigyelések a Jakabhegyi Homokkő Formáció DKDunántúli előfordulásaiban. Földtani Közlöny, 119: 359-371. (in Hungarian) ("Minerological-petrological observations on the Southeastern Transdanubian occurrences of the Jakabhegy Sandstone Formation") URL: http://epa.oszk.hu/01600/01635/00265/pdf/EPA01635_foldtani_kozlony_1989_1 19_4_359-371.pdf

Fülöp, J. 1990, Magyarország geológiája. Paleozoikum I. Magyar Állami Földtani Intézet, Budapest, 325 p. (in Hungarian) ("Geology of Hungary, Palaeozoic I”)

Gyalog, L. (Ed.) 2005, Magyarázó Magyarország fedett földtani térképéhez (az egységek rövid leírása (1:100 000). Magyar Állami Földtani Intézet, Budapest, 189 p. (in Hungarian and in English) ("Explanatory text of the 1:100 000 surface geological map series of Hungary (short descriptions of the Formations)")

Horváth, T. 2010, Megfigyelések a középső és késő rézkori kultúrák fazekasáruin Balatonőszöd-Temetői dűlő lelöhelyen. Készítéstechnikai vizsgálatok. Archeometriai Mühely (Archaeometry Workshop), 7(1): 51-82. (in Hungarian) (“Archaeological contribution to the study of the Middle and Late Copper Age pottery. Pottery manufacture”) Accessed: 28.02.2019. URL: http://www.ace.hu/am/2010_1/AM-10-01HT.pdf

Horváth, T. (Ed.) 2014, The prehistoric settlement at Balatonöszöd-Temetöi-dülö. Varia Archaeologica Hungarica Vol. 29. The Archaeological Institute of the Hungarian Academy of Sciences - Archaeolingua, Budapest, 733 p.

Horváth, T., S. Svingor, É., Molnár, M. 2006, Újabb adatok a Baden-péceli kultúra keltezéséhez. Archeometriai Mühely (Archaeometry Workshop), 3(3): 19-30. (in Hungarian) ("New data on the dating of the Baden-pécel Culture") Accessed: 28.02.2019. URL: http://www.ace.hu/am/2006_3/AM-2006-3-HT.pdf

Majoros, Gy. 1963, A Balatonmelléki permi rétegösszlet üledékföldtani vizsgálata. Ph.D. thesis at the Department of Petrology and Geochemistry (Faculty of Sciences), Eötvös Loránd University, Budapest, 57 p. (in Hungarian) ("Sedimentological study of the Permian Age sequences on the Balaton-Highland")

Majoros, Gy. 1998, A Dunántúli-középhegység újpaleozóos képződményeinek rétegtana. In: Magyarország geológiai képződményeinek rétegtana (Bérczi, I. \& Jámbor, Á., Eds.), MOL Rt. - Magyar Állami Földtani Intézet, Budapest: p. 119-147. (in Hungarian) ("Stratigraphy of the Upper Palaeozoic formations of the Transdanubian Range")

Máthé, Z. (Ed.) 1998, A Bodai Aleurolit Formáció minősitésének rövidtávú programja. Kutatási zárójelentés 4. kötet, Ásvány-közettani, közetgeokémiai és izotóptranszport vizsgálatok. Scientific report, Mecsekérc Környezetvédelmi Rt., Pécs, 76 p. (in Hungarian) ("Short-term classification program of the Boda Siltstone Formation Scientific final report tome 4., Mineralogical-petrographical, petro-geochemical and isotope-transport studies”)

McLennan, S.M. 2001, Relationships between the trace element composition of sedimentary rocks and upper continental crust. Geochemistry, Geophysics, Geosystems, 2(4): 24 p. doi:10.1029/2000GC000109

Palágyi, S., Csirke, O., Futó, J., Hlavay, J. Raucsik, B. Szabó, A. \& Vassányi, L. 2006, Mining Data from Roman Sandstone Quarries. Acta Archaeologica Academiae Scientiarum Hungaricae, 57: 395-422. doi:10.1556/AArch.57.2006.4.5 
Péterdi, B. 2011, Szerszámkövek és csiszolt kőeszközök archeometriai vizsgálatának eredményei (Balatonőszöd-Temetői dülö lelőhely, késő rézkor, bádeni kultúra). Ph.D. thesis at the Department of Petrology and Geochemistry (Faculty of Sciences), Eötvös Loránd University, Budapest, 157 p. (in Hungarian) (“Archaeometrical investigation on polished and other stone tools (Balatonőszöd-Temetői dülő (Hungary), Late Copper Age, Baden Culture”)

Péterdi, B., Szakmány, Gy., Judik, K., Dobosi, G., Kovács, J., Kasztovszky, Zs. \& Szilágyi, V. 2011, Bazalt anyagú csiszolt kőeszközök kőzettani és geokémiai vizsgálata (Balatonőszöd - Temetői dülő lelőhely). Archeomatriai Mühely (Archaeometry Workshop), 8(1): 33-68. (in Hungarian) ("Petrographical and geochemical investigation of polished stone tools made of basalt from the site Balatonőszöd - Temetöi dülö (Hungary)”) Accessed: 28.02.2019. URL: http://www.ace.hu/am/2011_1/AM-11-01PB.pdf

Péterdi, B., Judik, K. \& Dobosi, G. 2014a, Bazaltos lapillitufa anyagú őrlőkövek kőzettani és geokémiai vizsgálata (Balatonőszöd - Temetői dűlő lelőhely). Archeomatriai Mühely (Archaeometry Workshop), 11(2): p. 115-126. (in Hungarian) ("Petrographic and Geochemical investigation of grinding stones made of basaltic lapilli tuff (Balatonőszöd - Temetöi dülő site, Hungary)”) Accessed: 28.02.2019.

URL: http://www.ace.hu/am/2014_2/AM-14-02-PB.pdf

Péterdi, B., Szakmány, Gy., Judik, K., Dobosi, G., Kovács, J., Kasztovszky, Zs., Szilágyi, V. \& Gil, G. 2014b, Petrographic and geochemical investigation of a stone adze made of nephrite from the Balatonőszöd - Temetöi dülö site (Hungary), with a review of the nephrite occurrences in Europe (especially in Switzerland and in the Bohemian Massif). Geological Quarterly, 58(1): 181-192 + supplements. doi:10.7306/gq.1146

Pettijohn, F.J., Potter, P.E. \& Siever, R. 1973, Sand and Sandstone. Springer-Verlag, New York - Heidelberg - Berlin, 618 p.

Piros, L. 2010, Homokkö nyersanyagú köeszközök, szerszámkövek archeometriai vizsgálata, Gorzsa (DK-Magyarország). Master's thesis at the Department of Petrology and Geochemistry (Faculty of Sciences), Eötvös Loránd University, Budapest, 89 p. (in Hungarian) (“Archaeometrical investigation of stone tools, ground stones made of sandstone, Gorzsa (SE Hungary)”)

Sun, S.-S. \& McDonough, W.F. 1989, Chemical and isotopic systematics of oceanic basalts: implications for mantle composition and processes. In: Magmatism in the Ocean Basins (Saunders, A.D. \& Norry, M.J., Eds.), Special Publications Vol. 42, Geological Society, London: p. 313-345. doi:10.1144/GSL.SP.1989.042.01.19

Szakmány, Gy. 1996, Results of the petrographical analysis of some samples of the ground and polished stone assemblage. In: Excavations at Bicske-Galagonyás (part III). The Notenkopf and Sopot-Bicske cultural phases (Makkay, J., Starnini, E. \& Tulok, M., Eds.), Quaderno Vol. 6, Società per la Preistoria e Protostoria della Regione FriuliVenezia Giulia, Trieste: p. 224-241.

Szakmány, Gy. \& Nagy, B. 2005, Balatonlelle-Felső-Gamász lelőhelyről előkerült késő rézkori vörös homokkő őrlőkövek petrográfiai vizsgálatának eredményei. Archeomatriai Mühely (Archaeometry Workshop), 2005(II/3): p. 13-21. (in Hungarian) ("Results of petrographical analysis of red sandstone grinders from the Late Copper Age site Balatonlelle - Felső-Gamász.”) Accessed: 28.02.2019. URL: http://www.ace.hu/am/2005_3/AM-2005-3-SZGY.pdf 
Szakmány, Gy., Starnini, E., Horváth, F. \& Bradák, B. 2008, Gorzsa késő neolit tell településről előkerült kőeszközök archeometriai vizsgálatának előzetes eredményei (Tisza kultúra, DK Magyarország). Archeomatriai Mühely (Archaeometry Workshop), 2008(V/3): p. 13-26. (in Hungarian) ("Preliminary results of the archaeometric analyses of the stone artefacts from tell Gorzsa (Tisza Culture, Southeast Hungary)”) Accessed: 28.02.2019. URL: http://www.ace.hu/am/2008_3/AM-08-03-SZGY.pdf

Taylor, S.R. \& McLennan, S.M. 1985, The Continental Crust: its Composition and Evolution. Blackwell Scientific Publications Ltd., Oxford, 312 p.

Varga, A. 2009, A Dél-dunántúli paleozoos - alsó-triász sziliciklasztos kőzetek kőzettani és geokémiai vizsgálatának eredményei. Ph.D. thesis at the Department of Petrology and Geochemistry (Faculty of Sciences), Eötvös Loránd University, Budapest, 150 p. (in Hungarian) ("Petrology and geochemistry of the Palaeozoic-Lower Triassic siliciclastic rocks from Southern Transdanubia, Hungary”)

Varga, A., Raucsik, B., Szakmány, Gy. \& Máthé, Z. 2006, A Bodai Aleurolit Formáció törmelékes kőzettípusainak ásványtani, kőzettani és geokémiai jellemzői. Földtani Közlöny, 136(2): 201-232. (in Hungarian) ("Mineralogical, petrological and geochemical characteristics of the siliciclastic rock types of Boda Siltstone Formation.”) URL:http://epa.oszk.hu/01600/01635/00316/pdf/EPA01635_foldtani_kozlony_2006_13 6_2_201-231.pdf

Varga, A., Szakmány, Gy., Árgyelán, T., Józsa, S., Raucsik, B. \& Máthé, Z. 2007, Complex examination of the Upper Paleozoic siliciclastic rocks from southern Transdanubia, SW Hungary - Mineralogical, petrographic, and geochemical study. Sedimentary Provenance and Petrogenesis: Perspectives from Petrography and Geochemistry. Geological Society of America Special Paper Vol 420 (January 2007): 221-240. doi:10.1130/2006.2420(14)

Varga, A.R., Szakmány, Gy., Raucsik, B. \& Máthé, Z. 2005, Chemical composition, provenance and early diagenetic processes of playa lake deposits from the Boda Siltstone Formation (Upper Permian), SW Hungary. Acta Geologica Hungarica, 48(1): 49-68. doi:10.1556/AGeol.48.2005.1.2 